\title{
Stronger Together: Advancing a Global Bioarchaeology
}

\author{
Brenda J. Baker ${ }^{\mathrm{a} *}$ and Sabrina C. Agarwal ${ }^{\mathrm{b}}$ \\ ${ }^{a}$ Center for Bioarchaeological Research, School of Human Evolution \& Social Change, Arizona State \\ University, Tempe, AZ, USA \\ ${ }^{b}$ Department of Anthropology, University of California Berkeley, 232 Kroeber Hall, Berkeley, CA, USA \\ ${ }^{*}$ Correspondence to: Brenda Baker, Center for Bioarchaeological Research, School of Human Evolution \& \\ Social Change, Arizona State University, Tempe, AZ 85287-2402 \\ e-mail: bjbaker@asu.edu
}

ABSTRACT Bioarchaeology is a relatively young field that aims to improve our understanding of life, death, and interrelationships among past humans around the globe. The discipline grew out of 1960s American processual archaeology and biological anthropology and emerged as human osteoarchaeology in the UK. Today, bioarchaeology is a vibrant, interdisciplinary field of study that cross-cuts biological anthropology, archaeology, and social theory to situate past peoples within their biological, cultural, and environmental circumstances. The field emphasizes not only the study of human remains but the integrative analysis and interpretation of their context, including the archaeological, sociocultural, and political milieu and the environmental setting in which people lived. The growing interest in bioarchaeological research has created the need for a new peer-reviewed journal to help unify and advance this discipline around the globe. In this introduction to Bioarchaeology International, we trace the origins of the field and the different "schools" of bioarchaeology that have developed and are now merging as the discipline has matured. We then delineate the purpose and goals of the journal, highlighting how the articles in the first issue contribute to those goals. Finally, as co-editors in chief, we describe our vision for contemporary and future directions in bioarchaeology. With this overview of the field and journal, we wish to stimulate discussion and promote international submissions. We intend for Bioarchaeology International to strengthen this growing field and help promote scholarly and public interest in our collective research.

Keywords: archaeology; biological anthropology; biocultural; funerary archaeology; mortuary behavior; osteology; osteoarchaeology; paleopathology

Bioarchaeology is a burgeoning, integrative field that spans the globe. Bioarchaeology is often thought to encompass the study of only the human remains found within archaeological sites, frequently divorced from the contexts in which they were found. The physical remains of people store a record of their biological attributes, providing information on illnesses or trauma they survived or that may have contributed to their deaths, their daily activities, biological affinities, and more. Equally informative are the different ways that people were treated in death by those who survived them. Rather than investigating only the biological remains or studying material culture alone, integrating these components permits a more complete understanding of how people experienced an array of circumstances over the course of their own lives and through multiple generations. Differing subsistence practices, access to resources, exposure to hazards, and changes in economic, political, religious, or environmental factors over time and across vast areas of the world are topics explored by bioarchaeologists. Learning how past peoples were affected by pathogens, climate change, and immigration, for example, provides insight into contemporary issues and 
problems. Such studies demonstrate how bioarchaeology is relevant to multiple stakeholders and can inform the general public.

\section{The Development of Bioarchaeology}

Bioarchaeology as a field of research has had different trajectories related to variability in academic traditions between North America and those in Britain, France, and other countries (for detailed reviews, see Buikstra et al. 2011; Knüsel 2010; O'Donnabhain and Lozada 2014; Sheridan 2017). In North America, bioarchaeology grew out of processual archaeology and the "New Physical Anthropology" in the 1950s and 1960s, which began a shift from typological and descriptive studies to problem-oriented investigations of populations embedded within a biocultural paradigm (Armelagos 2003; Armelagos and Van Gerven 2003; Zuckerman and Armelagos 2011; Zuckerman and Martin 2016a). This "bio-cultural" perspective, which considers biological, cultural, and environmental factors in the study of past human populations, was promulgated by Don Brothwell (1967) of the UK (see also Roberts 2006). Incorporation of human osteologists and biological anthropologists, including George Armelagos, in large-scale rescue excavations of mortuary sites in southern Egypt and northern Sudan in the 1960s accelerated this paradigm shift (Baker 2016:183184; see Martin and Zuckerman 2016 for a review of Armelagos's influence on biocultural research). While the term "bioarchaeology" initially appeared in the late 1950s (Sheridan 2017:112) and was applied by Grahame Clark (1972) to the study of faunal remains from a Mesolithic site in Yorkshire (northern England), it was later used by Jane Buikstra (1977:69) to describe a regionally based, interdisciplinary research program in the lower Illinois River Valley that integrated archaeology and human osteology to investigate "biocultural change within the Woodland period."

In North America, the merging of archaeological and biological anthropological perspectives in the investigation of human remains on a regional scale over time has led to an integrative biocultural approach and promoted population-level analyses that marked a shift from the mostly descriptive studies that focused on measurement and classification of people and their diseases. Within American bioarchaeology, however, different schools of thought developed within the nascent discipline (Buikstra and Beck 2006; Rakita 2014; Stojanowski and Duncan 2014). The biocultural approach was championed by George Armelagos, his colleagues, and their students, who acquired broad training across the subfields of anthropology (Zuckerman and Martin 2016b). Jane Buikstra’s bioarchaeology emphasizes contextualization and integration of social theory with biological data from human remains (Buikstra et al. 2011; Buikstra and Beck 2006). Clark Larsen's definition of bioarchaeology focuses primarily on the interpretation of behavior from the human skeleton (as per the subtitle of his book; Larsen 1997, 2015). This perspective separated bioarchaeology from wider aspects of archaeological and social theory. Larsen's form of bioarchaeology has begun to recognize the linkage of archaeology and biological anthropology, acknowledging new developments that situate human biology within "the social past" (Larsen and Walker 2010:380) and relate to aspects of identity, gender, and other "social and cultural forces that leave their impression on the skeletal body" (Larsen 2015:xi). Clearly, the lines among these different perspectives both within and beyond North America are blurring as the field has matured.

The term "bioarchaeology," however, is not universally understood or applied globally. In the United States, "bioarchaeology" pertains to both mortuary site archaeology and human osteology, though these components frequently have been treated separately (see Goldstein 2006) and often continue to be separate purviews of archaeologists and "anthropologists" in many parts of the world, particularly where archaeologists are trained in classical or Near Eastern studies (see, e.g., Sheridan 2017). In France, different terminology is used for investigation of ritual surrounding death (les gestes funéraires), the study of field anthropology (anthropologie de terrain), or ancient burial (archéothanatologie) as it is now more commonly known (Knüsel 2010:68-69). Henri Duday's work, commencing in the 1970s (e.g., Duday 1978), has become widely influential, particularly since its more recent dissemination in English (e.g., Duday 2006, 2009), and is informing studies of body treatment, taphonomy, and commingling (e.g., Geber et al. and Haddow and Knüsel in this issue).

Although the biocultural paradigm links both British and American perspectives, "bioarchaeology" in the UK refers to the study of all ancient biological remains, including those of humans, animals, and plants, and more generally to environmental archaeology and paleoecology (Knüsel 2010:62-63). The study of faunal and human skeletal remains came to be known as "osteoarchaeology" (Roberts 2006:418). In the UK, osteoarchaeologists are found in departments of archaeology, whereas North American bioarchaeologists are typically housed in anthropology programs. In both the UK and North America, this field grew rapidly in the 1980s and 1990s. Training programs at the master's degree level were developed at multiple universities in the UK (Roberts 2006:430431 ), but only one specific master of arts graduate 
curriculum in bioarchaeology developed in the United States. Designed in the mid-1980s by a group of Arizona State University archaeologists and biological anthropologists led by Christopher Carr, Charles Merbs, and Christy Turner II, this curriculum required coursework in both archaeology and biological anthropology, producing bioarchaeologists trained in both these subfields of anthropology.

The field of bioarchaeology matured in the 1980s and 1990s, largely in response to major criticisms of methods and interpretations. The first potential death knell emerged with post-processual reevaluations of mortuary behavior (e.g., Chapman et al. 1981; Pader 1982; Parker Pearson 1982; Shanks and Tilley 1982) that challenged inferences about socioeconomic status based on grave attributes and inclusions as a straightforward reflection of social status (e.g., Binford 1971; Saxe 1972). Another serious challenge arose when the use of life tables in paleodemography was questioned and, at a more fundamental level, methods of estimating age from the skeleton were criticized for reflecting the structure of the sample on which they were based (Bocquet-Appel and Masset 1982). These criticisms met with numerous rebuttals (e.g., Buikstra and Konigsberg 1985; Van Gerven and Armelagos 1983) but spurred efforts to address the concerns in both archaeology (see Parker Pearson 1999) and biological anthropology. Improvements to existing techniques of age estimation (e.g., Brooks and Suchey 1990), development of new techniques (e.g., using the auricular surface [Lovejoy et al. 1985] and sternal ends of ribs [İşcan et al. 1984a, 1984b]), and new statistical approaches (e.g., transition analysis [Boldsen et al. 2002]) have helped allay these concerns. Additionally, more sophisticated and critically applied paleodemographic analyses have arisen that incorporate Bayesian statistics and hazards analysis (for more information concerning these developments see Chamberlain 2000; Hoppa and Vaupel 2002; and Milner et al. 2008) as well as fertility centered models (Jackes 2011).

Issues concerning demography and pathology subsequently were addressed in "The Osteological Paradox," an influential paper by Wood et al. (1992) that brought the issues of demographic nonstationarity, selective mortality, and heterogeneous frailty to the forefront 25 years ago. This work began perhaps an even more important critical examination of our approach to analyzing the skeletal samples that comprise much of bioarchaeological research. Like the critique of assumptions concerning mortuary practices and the "Farewell to Paleodemography," publication of "The Osteological Paradox" also met with substantial debate and discussion (e.g., Wright and Yoder 2003), yet the issues raised continue to be deliberated and new analytical approaches are being developed to address them in contemporary bioarchaeological research (DeWitte and Stojanowski 2015; see the section "Contemporary Directions" below for further discussion).

An additional obstacle in the field was spurred principally by repatriation legislation in the early 1990s, as it had already been recognized that data sets generated by different researchers frequently could not be compared due to a lack of standardized scoring criteria and publication of only summary statistics rather than raw data. Efforts were made by various organizations and groups of scholars to formulate standards for recording data that are widely used today (Brickley and McKinley 2004; Buikstra and Ubelaker 1994) and are being supplemented with new electronic database applications (e.g., Osteoware, the free database software for human skeletal remains [Smithsonian Institution, https://osteoware.i.edu]).

With the self-reflection on the development of the field in the early 2000s and recognition of continuing challenges (e.g., Agarwal and Glencross 2011; Buikstra et al. 2011; Buikstra and Beck 2006; Knüsel 2010), bioarchaeology is emerging as a more robust field of inquiry that engages social theory more fully and frequently to contextualize biological information gleaned from human remains. Bioarchaeologists regularly address questions of both cultural and biological significance through integration of research involving human remains, their burial sites, and their curation. Recent work, as outlined below, is contextualizing our understanding of humanity through the lens of the life course, from fetus to death, and over generations, recognizing that rituals surrounding death and body treatment as a form of material culture involve the interaction of both the living and dead. Such research serves to bridge the gap that has previously existed between archaeologists and bioarchaeologists and help unify the different research trajectories that developed in the early decades of bioarchaeological inquiry.

\section{Contemporary Directions}

Contemporary bioarchaeology continues to emphasize both contextual and multi-scalar approaches. While there remains a focus on population-level trends in the field, there has been a shift to consider and integrate a focus on the individual life course in bioarchaeological research. At the same time, the field has continued to embrace the use of innovative methods in geospatial analysis, (micro)imaging, and molecular and chemical analysis, coupled with ecological, ethnographic, and historical approaches. Recent research in bioarchaeology allows the exploration of 
broad issues that encompass growth, health, demography, human ecology, sociopolitical and subsistence transitions, epigenetics and developmental biology, and social theoretical approaches to understanding the conceptualization of mortuary landscapes, spatial organization of cemeteries, embodiment of social identity, and more. Bioarchaeologists are addressing questions of great relevance to modern issues, including the effects of climate change, demographic and epidemiological transitions, inequality, and migration. We outline here some of the major directions in the contemporary field, although it is certainly not exhaustive. Our aim is to showcase many of these current directions of research in the coming issues of Bioarchaeology International.

Although researchers have slowly addressed the complex issues raised by the osteological paradox, its use as a worthy research endeavor in itself has emerged only recently (DeWitte and Stojanowski 2015). Several innovative studies have embraced the investigation of selective mortality and heterogeneous frailty through an examination of specific mortality risks associated with factors such as age, sex, and non-specific indicators of stress (e.g., Boldsen 2007; DeWitte 2009; DeWitte and Bekvalac 2010; DeWitte and Hughes-Morey 2012; DeWitte and Wood 2008; Marklein et al. 2016; Wilson 2014). Differential frailty and risk of death for subgroups that are identified through archaeological evidence or mortuary context now are more frequently investigated (e.g., DeWitte 2010; Stojanowksi 2013; Storey et al. 2012; Sullivan 2005).

Contemporary studies continue to clarify the interpretation of skeletal stress indicators in relation to risk of death in distinct age cohorts, such as preadults versus surviving adolescent or adult cohorts. While early studies such as that by Saunders and Hoppa (1993) suggested there was no association with indicators of stress (specifically, stunted growth) and risk of death, more recent research supports the relationship of stress indicators and increased risk of death, and demonstrates high frequencies of stress lesions in the very youngest age groups and recovery from stress in older cohorts (Littleton 2011; Perry 2014; Robbins Schug 2011). In particular, new studies highlight relationships between stress indicators and mortality, with influences from factors such as gender or status (Vercellotti et al. 2014) or early diet (weaning) patterns (for a recent review see Tsutaya and Yoneda 2015).

Interest in assessing the consequences of childhood stress for later risk of death and morbidity also has prompted bioarchaeologists to engage more directly with concepts of epigenetics and, particularly, what has been termed the Barker hypothesis or, more recently, the developmental origins of health and disease (DOHaD) hypothesis (Agarwal 2016; Gowland 2015b; Klaus 2014). Following an early study by Armelagos et al. (2009), researchers have tested the $\mathrm{DOHaD}$ hypothesis using bioarchaeological data on dental defects (enamel hypoplasias) and adult health and mortality (e.g., Amoroso et al. 2014; Temple 2014; Weisensee 2013). This research is enhanced by analysis of stable isotopes from different parts of bones and teeth and among teeth that form at different times to reveal diet change over the life course and gain a better understanding of individual life histories, even in commingled deposits (e.g., Gregoricka 2014; Gregoricka et al. 2017). New techniques that examine serial (incremental) sections of tooth dentine (e.g., Beaumont et al. 2013; Burt and Garvie-Lok 2013; Eerkens et al. 2011), along with analyses of bone collagen and apatite, are advancing our understanding of the weaning process and the identification of a weaning diet, a post-weaning diet, and the age at which an adult diet is adopted (e.g., Dupras and Tocheri 2007; Eerkens and Bartelink 2013; Richards et al. 2002; Waters-Rist et al. 2011). These methodological advances have led to a proliferation of research that has begun to tease out biocultural and environmental influences on past communities and contribute to the elucidation of relationships among diet, morbidity, and mortality in various subgroups (e.g., Bourbou et al. 2013; Gregoricka and Sheridan 2012; Henderson et al. 2014; Kaupová et al. 2014; Prowse 2011; Reitsema and Vercelloti 2012; Reitsema et al. 2016; Sandberg et al. 2014). Additional tests of hypotheses concerning developmental pathways of health in the past and potential multigenerational effects (see, e.g., Beaumont et al. 2015) will require multifaceted approaches to investigating the linkage between morbidity and mortality and address the osteological paradox. Such research clearly illustrates the maturation and breadth of contemporary bioarchaeology.

Diet in the past also is being investigated through a life-course approach. When combined with archaeobotanical and zooarchaeological information, stable isotope analysis is the gold standard method for reconstructing diet, subsistence, and even for examining land-use strategies and environments of past populations (e.g., Fraser et al. 2013; Iacumin et al. 2016). Biogeochemical research once provided only an average of what a person consumed over many years based on bulk bone collagen values, although tissue and hair samples in well-preserved assemblages permitted a window into diet during shorter intervals much closer to the person's death (e.g., White and Schwarcz 1994). Stable isotopes of strontium and oxygen now go well beyond diet reconstruction and are used regularly to trace residential mobility and identify immigrants within a cemetery, providing further insight into life histories of individuals and social networks 
and population movements in the past (e.g., Bentley et al. 2009; Gregoricka and Sheridan 2017; Killgrove and Montgomery 2016; Neil et al. 2016; Parker Pearson et al. 2016; Shaw et al. 2015; Valentine 2016; Wright 2012). Stable isotope research is illuminating new aspects of urbanization, immigration, colonization, interaction, and identity (e.g., Buzon and Simonetti 2013; Knudson 2011; Knudson et al. 2014). In fact, more holistic and multidisciplinary approaches to the investigation of migration, culture contact, and colonization have been revitalized in bioarchaeology (Baker and Tsuda 2015; Cabana and Clark 2011; Murphy and Klaus 2017).

Recent studies of bone mass and biomechanics also have begun to consider life-course approaches and the role of growth on bone remodeling (Agarwal 2016). For example, changes in cross-sectional bone geometry along with indicators of stress during growth explore trade-offs between bone development and morphology over the life course (Robbins Schug and Goldman 2014; Temple et al. 2013). The critical evaluation of skeletal alterations at sites of tendon and ligament attachments, their etiology, and their relationship to pathological processes as well as habitual activities (Henderson and Alves Cardoso 2012; Jurmain et al. 2012) also has led to new investigations of entheseal changes and their development over the life course (Villotte and Knüsel 2012). While primate functional adaptation in bone morphology is well studied in paleoanthropology and primatology, bioarchaeologists are uniquely positioned to investigate the larger synergistic relationships between social behavior, context, and bone adaptation in the human skeleton across different human communities through time.

Along with continued attention in bioarchaeology to health and frailty in the past, significant effort has been directed toward refining our methods for diagnosing skeletal indicators of disease and clarifying our interpretation of lesions in ancient bones. For example, new research is challenging our traditional interpretation of non-specific indicators of stress as measures of health status (Reitsema and Mcllvaine 2014), including dental enamel defects (Hassett 2014; Hubbard et al. 2009), periosteal reaction (e.g., DeWitte 2014a, 2014b; DeWitte and Wood 2008; Weston, 2008, 2009, 2012), and porotic hyperostosis (McIlvaine 2013; Piperata et al. 2014), as well as specific patterns of pathology that are diagnostic of metabolic conditions such as scurvy (Crandall and Klaus 2014) and anemia (Smith-Guzman 2015), and infections such as leishmaniasis (Marsteller et al. 2011). The study of disease progression over the life course also is being examined more broadly in contemporary studies of paleopathology that also draw upon medical sources (e.g.,
Baker and Bolhofner 2013). Data from both clinical and medical anthropological sources are used increasingly, and we expect work to continue in these areas in both living populations and skeletal assemblages to improve the understanding of pathological lesions in bioarchaeological research.

Contemporary bioarchaeological analyses of health also use state-of-the-art technology. Imaging technology such as computed tomography (CT) scanning (O'Brien et al. 2009) and X-ray microtomography (micro-CT) analysis (Booth et al. 2016), histology (Crowder and Stout 2011), stable isotope analyses, ancient DNA analysis (aDNA), immunology, and parasitology (Reinhard and Araújo 2012) are now at the forefront of paleopathological diagnosis. The fastpaced advances in biogeochemical analyses and molecular biology have pushed bioarchaeological studies in new directions. Stable isotope analyses, for example, increasingly are being used to investigate malnutrition and disease (Beaumont and Montgomery 2016; D’Ortenzio et al. 2015; Katzenberg 2012; Olsen et al. 2014) as well as disease transmission in the past (Kendall et al. 2013; Roberts et al. 2013). Similarly, analysis of aDNA has gone well beyond confirming the presence of particular conditions in pathological skeletons, revolutionizing our understanding of the origins and evolution of disease (Anastasiou and Mitchell 2013; Harkins and Stone 2014; Wilbur and Stone 2012). Research has emphasized the co-evolution of humans and pathogens, including the causative organisms of tuberculosis, leprosy, and plague (e.g., Bos et al. 2011, 2014; Müller et al. 2014; Stone et al. 2009) and investigated the spread of various pathogens both temporally and geographically (e.g., de Melo et al. 2010; Schuenemann et al. 2013). Anthropological geneticists are also analyzing aDNA to investigate disease susceptibility, for example, examining how North American indigenous populations responded and adapted to new diseases and epidemics such as smallpox upon contact (Lindo et al. 2016). Evidence of cytosine methylation also is being recovered from ancient bone (Gokhman et al. 2014; Smith et al. 2015), shedding light on how epigenetic changes could have related to physiological stress in the past and how these changes could alter bone plasticity and growth. Past immunological studies using ELISA to investigate antigens or antibodies of parasites that cause malaria and schistosomiasis, for example, have been critiqued (e.g., Sallares and Gomzi 2001), but biomolecular investigations have progressed to encompass analysis of cortisol levels in ancient hair samples that demonstrate individual experiences of physiological stress (Webb et al. 2009) and experimental work that will aid our understanding of inflammatory responses in past populations 
(Crespo et al. 2016). Finally, advances in paleomicrobiology are providing insight into the human microbiome and enhancing dietary reconstruction thorough extraction of chemical compounds, aDNA, and microfossils from ancient dental calculus and archaeological coprolites (Buckley et al. 2014; Radini et al. 2017; Schnorr et al. 2016; Warinner and Lewis 2015; see also Velsko and Warriner in this issue), applications that will surely continue to expand in the coming several years.

Along with the concerns about demography and differential frailty in archaeological samples, there has been a new critical examination of the representativeness of institutionally housed skeletal samples. For example, bioarchaeologists are looking more closely at issues of racism, violence, and health disparities in documented and cadaveric skeletal samples (de la Cova 2010; Nystrom 2014, 2017). This recent research has revealed aspects of institutionalization and social marginalization historically and has triggered a renewed dialogue on the ethics and scientific use of anatomical collections both in the past and the present. This deep concern for how we study and represent the dead in bioarchaeological research is certainly part of the contemporary landscape of the field well beyond the passage of the Native American Graves Protection and Repatriation Act (NAGPRA) in the United States in 1990, and it forms a new "ethos" of bioarchaeology (Martin et al. 2013:23). Both in North America and globally (Márquez-Grant and Fibiger 2011), bioarchaeology is forging a new commitment to how we engage with repatriation (Kakaliouras 2012, 2017; Pérez 2010) and ethical practice with community stakeholders and the public (Martin et al. 2013:23-55; Roberts 2009:17-34; Turner and Andrushko 2011). While bioarchaeologists still have much work to do to go beyond consent with stakeholders to achieve a truly collaborative practice (Atalay 2006), this recent work demonstrates a new direction in the field toward a larger goal of community-engaged scholarship.

With its focus on criminal and humanitarian issues, forensic anthropology is deeply engaged with the public and local communities. Although forensic anthropology is a methodologically focused and applied specialty, there has been a movement in recent years to ally the practice with bioarchaeology more closely in order to bring a more holistic and anthropological approach to the field (e.g., Crossland and Joyce 2015). Undocumented border crossers, for example, are generally underprivileged people subjected to hardships or maltreatment that may result in death during their journeys (see Kuba 2012 for a recent review). Forensic anthropologists have begun applying bioarcheological tools such as stable isotope analyses to determine area of origin or evaluate the frequency of skeletal stress indicators to identify undocumented migrants (Beatrice and Soler 2016; see also review by Kuba 2012). Forensic anthropologists are particularly interested in the study of violence in the recent past and the present day. Because violence afflicts contemporary society, and the human capability for violence continues to capture public attention, a large amount of bioarchaeological research has been devoted to understanding violence in the past. Current bioarchaeological approaches to the study of interpersonal and structural violence (e.g., Harrod and Martin 2014; Knüsel and Smith 2014; Kurin 2016:127153; Martin et al. 2012; Martin and Tegtmeyer 2017; Nystrom 2014, 2017; Redfern 2017) thus are a vital contribution to our understanding of violence throughout human history and in today's world.

Another trajectory that has driven contemporary research in bioarchaeology is a concern with the reconstruction of social identity in the past. Many contemporary bioarchaeologists have keenly engaged with social theory in their approach to identities based on gender, age, or health (Knudson and Stojanowski $2008,2009)$. Theoretically groundbreaking work is grappling with the limitations of the binary nature of biological sex and the traditional use of heteronormative interpretations of gender roles from skeletal remains (Agarwal 2012; Geller 2005, 2009, 2017; Hollimon 2011; Sofaer 2006a). Similarly, life-course and embodiment perspectives continue to push our study of age and growing old in the past (Appleby 2010; Gowland 2009, 2015a). This type of research is part of the rapidly developing theoretical approach to viewing the skeleton as a form of material culture crafted through lived experience, which blurs the division of the biological and social body (Sofaer 2006b). Similar approaches are being taken with the interpretation of skeletal data from preadult skeletons in an attempt to understand the lives of children in the past (e.g., Halcrow and Tayles 2011; Littleton 2011; Thompson et al. 2014; Wheeler 2010; Wheeler et al. 2013). The effort to illuminate group and individual identity is also seen in the recent interest in the bioarchaeology of care (Tilley 2015; Tilley and Schrenk 2017), which considers aspects of illness and caregiving in the past.

A resurgence of research focused on individual identity and the lived experience through osteobiographic approaches pioneered by Frank Saul (1972; Saul and Saul 1989) has also occurred (Baadsgaard et al. 2011; Stodder and Palkovich 2012). This approach is not a move away from population-focused research, which is still very much the basis of contemporary bioarchaeology research. Instead, it is related to the increasing desire for more humanistic approaches in the field and the appreciation of what the lived experiences of individuals within a group can reveal to contextualize our understanding of the population-level responses to biological, cultural, and environmental 
factors. A related approach is biohistory (e.g., Stojanowski and Duncan 2016), which involves the investigation of identified historical figures who are often well known, such as Richard III (Buckley et al. 2013; The Greyfriars Research Team with Maev Kennedy and Lin Foxhall 2015) or King Tutankhamun (e.g., Rühli and Ikram 2013). Individual-level research represented by osteobiography and biohistory often is best suited to engagement with students and the public so they can relate to these past people through their own experiences.

Bioarchaeology must incorporate the archaeological contextual analysis of sites and skeletal remains by integrating them within the landscape and through analysis of the spatial organization, grave styles, body position and orientation, grave inclusions, and the relationships to other sites and landmarks. More bioarchaeologists who focus on skeletal remains have begun to recognize that questions concerning identity, for instance, can only be answered fully by considering both archaeological and biological data. For example, intrasite biodistance studies that estimate the degree of relatedness among those interred have embraced spatial analysis to reconstruct cemetery structure and formation and to discern its underlying organizing principles that relate to grave placement, particularly in regard to biological relationships among the deceased. Such research may demonstrate kin-structured organization (e.g., Paul et al. 2013; Pilloud and Larsen 2011; Sciulli and Cook 2016) and permit insight into variation in health and diet within a community and even among families (e.g., Stojanowski 2013). Spatial analysis technology such as geographic information systems (GIS) is now commonly used in archaeological projects, including those focusing on sites containing human remains (e.g., Herrmann 2002; Wilhelmson and Dell'Unto 2015). Recent applications of GIS compare pathology and status within an analytic framework to investigate health and disease patterns in the past (Herrmann et al. 2014; Stojanowski 2013).

Consideration of taphonomic site formation processes and the effects of corpse treatment on the production of archaeological skeletal assemblages is becoming more common and provides new insights into mortuary behaviors in past communities, thereby enhancing our understanding of a community's perceptions of death, transformation, and memory (e.g., Geber et al. in this issue; Robb et al. 2015; Smith and Pérez Arias 2015; Weiss-Krejci 2011). GIS and threedimensional photogrammetry are proving particularly useful in understanding how site formation factors and body processing (e.g., defleshing, cremation), curation of elements, the reuse of graves, and patterns of purposeful disturbance are linked to ongoing relationships between the living and the dead (e.g., Haddow and
Knüsel in this issue). The lived experiences of individuals embodied in their remains and the performed identities and experiences evidenced in mortuary contexts are instrumental in new approaches to investigating social inequality in the past. Quinn and Beck (2016), for example, propose that the degree of coherence or dissonance found across multiple social dimensions is indicative of social organization, and they present three cases studies that examine institutionalized inequality in prehistoric Europe.

While the preceding types of research are more integrative, much more multidisciplinary collaborative work, particularly research including archaeologists, bioarchaeologists, and others with differing areas of expertise, is needed to advance our understanding of the human experience. There are still too many situations in which the human remains are a low priority, even for projects involving excavation of ancient cemeteries (see Sheridan 2017), and many collections of human remains for which archaeological documentation is lacking for a variety of reasons, thus limiting research potential beyond the bones. Over the last several years, however, many projects have become increasingly collaborative endeavors. Projects may be directed by a bioarchaeologist overseeing a team with differing areas of expertise, have co-directorships of an archaeologist and a bioarchaeologist, integrate bioarchaeologists into both field and lab components of a project, or are partnerships on broad research projects involving previously excavated material that are enriched by cooperation (examples include, among many others, Baker 2016:191-193; Binder and Spencer 2014; Buzon et al. 2016; Carr and Case 2005; and Case and Carr 2008). Recent works on the archaeology of death and burial reflect such collaboration and are more inclusive of archaeological, biological, and cultural perspectives (see, e.g., the representation among chapters in Tarlow and Nilsson Stutz 2013 and Wrobel 2014). These trends are encouraging and point to more cooperative engagement in the future.

\section{The Need for Bioarchaeology International}

The field of bioarchaeology has flourished in the early twenty-first century, accounting for a significant proportion of recent tenure-track academic positions in anthropology in North America (Stojanowski and Duncan 2014:56) and in archaeology departments globally. Numerous graduate and senior researcher grants for bioarchaeological projects are awarded by the National Science Foundation and the WennerGren Foundation for Anthropological Research in the United States, the Social Science and Humanities Research Council in Canada, the Wellcome Trust and the Leverhulme Trust in the UK, and many other 
agencies around the world. In North America, bioarchaeologists constitute a substantial portion of the American Association of Physical Anthropologists (AAPA), the Canadian Association of Physical Anthropologists (CAPA), and the Society for American Archaeology (SAA). Bioarchaeology podium sessions have comprised a significant number of the Biological Anthropology Section sessions at the American Anthropological Association annual meetings in the past several years. Meetings of regional bioarchaeological associations in the United States, including the Midwest Bioarcheology and Forensic Anthropology Association (BARFAA), the Western Bioarchaeology Group (WeBiG), and the Bioarchaeologists' Northeast Regional Dialogue (BNRD), are well attended. Organizations with a substantial focus on bioarchaeology also are prominent in other countries, such as the British Association for Biological Anthropology and Osteoarchaeology (BABAO).

Despite maturation of bioarchaeology as a field of inquiry and its tremendous growth, there is no dedicated, integrative peer-reviewed journal for this field as a whole. Established journals tend to focus on skeletal remains (e.g., American Journal of Physical Anthropology, International Journal of Osteoarchaeology, International Journal of Paleopathology), are archaeology outlets appropriate for articles emphasizing the mortuary context or ritual behavior (e.g., American Antiquity, Antiquity), or are more methodologically (e.g., Journal of Archaeological Science) or theoretically (e.g., Journal of Archaeological Research) oriented. Because these traditional divisions between biological and archaeological emphases and even between more theoretical and empirical research persist in our principal journals, integrative work often does not fit well within the scope of one type of journal or the other. Regional journals form another outlet for bioarchaeological research, yet these publications may not be consulted regularly by those working outside that area, hindering the exchange of ideas among scholars investigating related research questions or working in similar environmental or social contexts. Although edited volumes have been a major publication venue for bioarchaeologists since the 1990s, with bioarchaeology book series promulgated by the University Press of Florida, Cambridge University Press, and Springer (see Sheridan 2017 for a valuable summary table), current tenure and promotion criteria in North American and British institutions frequently devalue book chapters in comparison to peer-reviewed journal articles.

Bioarchaeology International provides a new outlet for rigorous peer-reviewed publication of substantive articles that will help unify this growing field and provide a global perspective. The overarching goal is to publish studies that are contextually and theoretically informed and that explore the human condition and ways in which human remains and their funerary contexts can provide unique insight on variation, behavior, and lifestyle of past people and communities. Original research articles, brief reports, and invited commentary essays related to the study of archaeological human remains and mortuary sites will be published quarterly. Occasionally, Bioarchaeology International will publish thematic issues. Thematic issues may build upon conference symposia or arise anew. Our well-respected advisory and editorial board members work in seven different countries, helping recruit manuscripts and reviewers because the journal is intended to be global in both content and readership. To facilitate this international perspective, authors are asked to supply their abstracts in a language other than English. This requirement will improve the visibility of the published article, particularly in situations where the alternate-language abstract is that of the country where the author conducted the research or is employed. Publication of theoretical, topical, and data-oriented research spanning different regions and temporal periods will appeal to a broad range of scholars, students, and professionals in the fields of bioarchaeology, archaeology, biological/physical anthropology, anthropology, paleopathology, human biology, history, medicine, geography, and other related fields. Commentary pieces are intended to promote discussion among readers on current issues and themes in the field or to discuss new research directions that may advance the field. Letters to the editors in chief may be submitted to facilitate discussion or alert colleagues to new information concerning collections, methods, projects, and so forth. A feature that sets Bioarchaeology International apart is the professional copyediting of accepted manuscripts provided by the University of Florida Press.

Our first issue exemplifies the international reach of the journal. Authors are affiliated with institutions in six countries. The collected research articles include work in Sudan, Turkey, the UK, and Ireland, and our alternate-language abstracts in this issue are in four different languages-Arabic, French, German, and Spanish. The concern with archaeological context pervades the research articles in this issue and illustrates recent developments in bioarchaeology that integrate trends highlighted above in American, British, and French perspectives. For example, Sarah Schrader and Michele Buzon examine entheseal changes and accidental trauma in concert to help understand changes in activities and risk that may have occurred during the period of Egyptian colonization in the New Kingdom to the postcolonial era during which a new state developed in ancient Nubia. While at first glance this article may appear to be a typically skeletally focused contribution, the authors stress the 
investigation of lived experiences of groups of people and the insight such studies provide into understanding population resilience during the imposition and subsequent collapse of a colonial empire.

Two articles in this issue explore burial treatment and taphonomy. Jonny Geber and colleagues and Scott Haddow and Christopher Knüsel discuss treatment of the dead by the living and the careful recording during excavation that allows the reconstruction of processes that resulted in the mixing of individuals, reuse of skeletal elements or graves, and the social meaning of these manipulations in very different contexts in Neolithic Ireland and Turkey. The juxtaposition of these articles raises points about information gained through restudy of assemblages excavated long ago (Geber et al.) and through careful stratigraphic analysis of skull retrieval and secondary burial afforded by thorough excavation records, 3D modeling of graves, and GIS spatial analysis (Haddow and Knüsel). These articles should be of interest to scholars investigating body treatment, secondary burial, and retention or reuse of skeletal elements from sites in different regions or periods. Additional discussion of the importance of site stratigraphy in bioarchaeological research is provided by Bennjamin Penny-Mason in his study of use of the Harris Matrix and phasing of burials within cemeteries. He indicates the difficulty of reconstructing site stratigraphy from field records but provides evidence to show that it is preferable to undertake such time-consuming work than to group the burials together in one, often long, temporal span. His examples show the impact that lumping and splitting individuals from different phases of cemeteries excavated in the UK has on the interpretation of pathology within that skeletal assemblage. Although Penny-Mason's examples are specific to the $\mathrm{UK}$, his findings are of interest to anyone investigating assemblages from cemetery sites, whether focusing on skeletons or grave architecture and artifacts. Understanding phases of use within a cemetery is integral to any investigation of ritual, identity, pathology, or change through time.

Finally, commentary on bioarchaeology of the oral microbiome transcends geography. This issue's invited essay by Irina Velsko and Christina Warinner highlights new advances in investigating the DNA and proteins of microbes found in dental calculus to gain information on human health and biology, human and pathogen co-evolution, and diet in past peoples.
Recommendations for handling and sampling dental calculus from the field to lab will promote future studies. We hope that the utility of investigations on the oral microbiome will spread by word of mouth!

\section{Conclusion}

Contemporary bioarchaeology is a field with many arms-some focus their research on methodological and technical specialties of bony analysis, or carefully trace mortuary and burial context, while others interpret data with an infusion of social theory and narrative. These branches of the field are no longer disparate. Many of today's scholars are more at ease with, and seek to engage in, multiple modalities of inquiry. The current field is united in its commitment to understand the human experience within a contextual and ethical framework. We are pleased for Bioarchaeology International to represent this vision of the field and present a new forum to encompass this expanding and exciting field.

\section{Acknowledgments}

We wish to thank Meredith Morris-Babb, director of University Press of Florida, for her interest in creating a new journal in bioarchaeology and support of this endeavor. Lauren Phillips, journals manager at the press, has provided endless help in setting up our manuscript submission site, web page, and myriad mechanics needed to bring the journal to fruition. Katherine Kinkopf (University of California, Berkeley), our editorial assistant, has also managed our system adeptly, and her help in keeping the workflow with manuscripts going smoothly is appreciated. Jonathan Lawrence has done excellent work as the journal's copy editor. We are grateful to our advisory and editorial board members for their enthusiasm and encouragement. Comments on an earlier draft of this paper were graciously provided by Troy Case, Tina Jakob, Katie Kinkopf, Judith Littleton, and Gwen Robbins Schug. Abstracts were translated into Arabic by Mohamed Faroug Ali, Chinese by Shih-Shun Lee and Mei-Chih Lee, French by Isabelle Crevecoeur, German by Tina Jakob, and Spanish by Tiffiny Tung. We also thank Christine Lee for facilitating the Chinese translation.

La bioarchéologie est une discipline relativement jeune qui a pour objectif d’améliorer notre compréhension de la vie, de la mort et des interrelations entre les populations humaines passées à l'échelle du monde entier. Cette discipline est née de l'archéologie processuelle américaine et de l'anthropologie biologique dans les années 1960, et a émergé en tant qu'ostéo-archéologie humaine au Royaume-Uni. Aujourd'hui, la bioarchéologie est un champ d'étude dynamique et interdisciplinaire au croisement de l'anthropologie biologique, de l'archéologie et des 
théories sociales. Elle cherche à appréhender les populations humaines passées en tenant compte du contexte biologique, culturel et environnemental. Cette discipline met l'accent non seulement sur l'étude des restes humains, mais également sur l'analyse et l'interprétation intégratives de ces données dans leur cadre archéologique, socioculturel, politique, et environnemental. L'intérêt croissant pour les recherches en bioarchéologie est à l'origine de la nécessité de créer un nouveau journal évalué par les pairs afin d'unifier et de faire progresser cette discipline dans le monde entier. Dans cette introduction à Bioarchaeology International, nous retraçons les origines de la discipline et les différentes “écoles” de bioarchéologie qui se sont développées et qui tendent maintenant à fusionner à mesure que la discipline mûrit. Nous décrivons ensuite l'ambition et les intentions de la revue, en soulignant l'adéquation des articles du premier numéro avec ces objectifs. Enfin, en tant que co-rédactrices en chef, nous décrivons notre vision des orientations actuelles et futures de la bioarchéologie. Avec cet aperçu de la discipline et du journal, nous souhaitons encourager la discussion et promouvoir les soumissions internationales. Nous espérons que Bioarchaeology International viendra renforcer cette discipline en plein essor et aidera à promouvoir l'intérêt scientifique et public pour notre recherche collective.

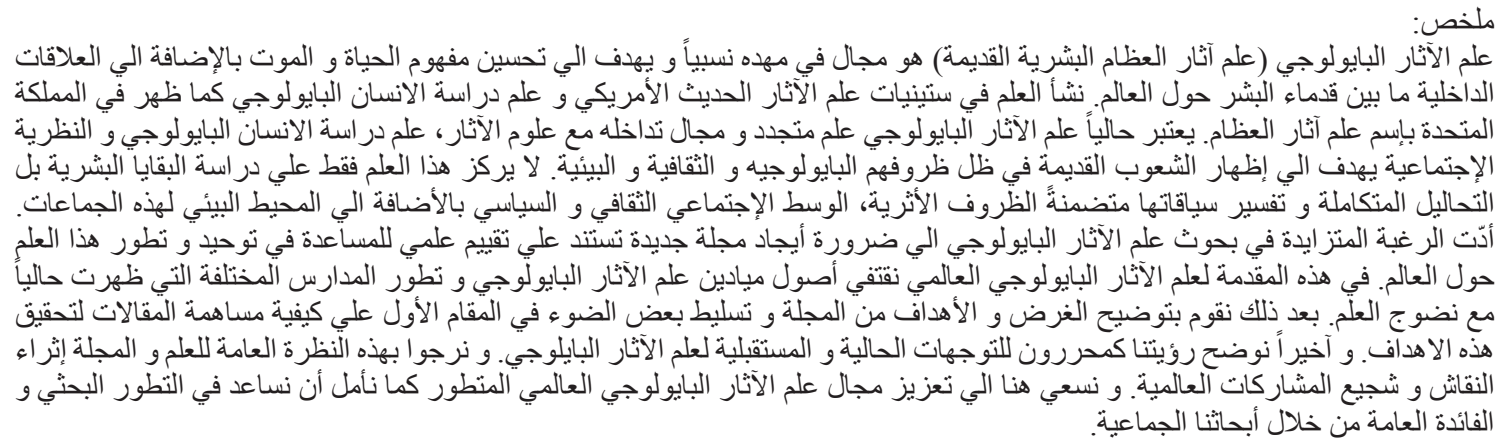

La bioarqueología es un campo de estudio relativamente joven que tiene como objetivo mejorar nuestra comprensión de la vida, la muerte y las interrelaciones entre los humanos del pasado en todo el mundo. La disciplina surgió de la arqueología "procesual" y de la antropología biológica en los EE UU de los años 60, y surgió como osteoarqueología humana en el Reino Unido. Hoy en día, la bioarqueología es un campo de estudio vibrante e interdisciplinario que integra la antropología biológica, la arqueología y la teoría social para situar a las comunidades del pasado en sus contextos biológicos, culturales y ambientales. El campo enfatiza no sólo el estudio de los restos humanos, sino también la integración del análisis e interpretación de sus contextos, incluyendo el arqueológico, sociocultural y político, así como el ambiente en el que vivió la gente. El creciente interés en la investigación ha creado la necesidad de una nueva revista revisada por pares para ayudar a unificar y avanzar esta disciplina en todo el mundo. En esta introducción a Bioarchaeology International, trazamos los orígenes del campo y las diferentes "escuelas" de bioarqueología que se han desarrollado y ahora se están fusionando a medida que la disciplina ha madurado. Luego delineamos el propósito y objetivos de la revista, destacando cómo los artículos en la primera edición contribuyen a esos objetivos. Finalmente, como Co-Editores, describimos nuestra visión para las direcciones contemporáneas y futuras en la bioarqueología. Con esta visión general del campo y la revista, deseamos estimular el debate y promover las presentaciones de manuscritos internacionales. Nuestra intención es que Bioarchaeology International fortalezca este campo creciente y ayudar a promover el interés académico y público en nuestras investigaciones colectivas.

Bioarchäologie ist ein reltiv junges Forschungsgebiet, das die Verbesserung unserer Verständnisse von Leben, Tod und den Verbindungen archäologischer Bevölkerungsgruppen weltweit miteinander zum Ziel hat. Die Disziplin erwuchs aus der nordamerikanischen prozessualen Archäologie und physischen Anthropologie der 1960er Jahre und enstand als Human-Osteoarchäologie in Grossbritannien. Heutzutage ist die Bioarchäologie ein lebendiges, interdisziplinäres Gebiet, das übergreifend die biologische Anthropologie, Archäologie und Sozialtheorie umfasst, um archäologische Bevölkerungen in ihren biologischen, kulturellen und ökologischen Rahmen zu stellen. Die Bioarchäologie beinhaltet nicht nur das Studium menschlicher Überreste, sondern auch die integrative Analyse und Interpretation der Lebensumstände, insbesondere des archäologischen, soziokulturellen und politischen Milieus und der Umwelt, in der die Menschen lebten. Dieses wachsende Interesse an der bioarchäologischen Forschung hat es notwendig gemacht eine neue Peer-Review-Fachzeitschrift zu erschaffen, die helfen soll die Disziplin weltweit zu vereinen und voranzutreiben. In diesem Einführungsartikel zu Bioarchaeology International verfolgen wir die Ursprünge und die verschiedenen "Schulen“ der Bioarchäologie, die sich entwickelt haben und die im Zuge der Weiterentwicklung der Disziplin verschmelzen. Desweiteren werden die Zwecke und Ziele der Fachzeitschrift definiert und es wird dargelegt, wie die Beiträge in dieser ersten 
Ausgabe zu diesen Zielen beitragen. Abschliessend beschreiben wir als Cefredakteurinnen unsere Vision für zeitgenössische und zukünftige Forschungrichtungen der Bioarchäologie. Mit diesem Überblick über die Disziplin und die Fachzeitschrift wollen wir Diskussionen anregen und internationale Beiträge fördern. Es ist unsere Absicht für Bioarchaeology International dieses wachsende Forschungsgebiet zu stärken und zu helfen, das wissenschaftliche und öffentliche Interesse in unsere gemeinschaftliche Forschung zu unterstützen.

生物考古學是一個比較年輕的領域, 其目的是在改善我們對過去地球上人類的生活, 死亡及相互間的関係作 進一步的瞭解, 這個學科是從1960年代美國流程考古學及生物考古學在英國演變而成的人類骨頭考古學。生 物考古學現在是一個很活躍跨領域的學科, 它蓋括生物考古人類學, 考古學, 以及社會理論, 把過去人類在生 物, 文化, 生活環境的種種情況放在應有的階位上, 這個領域不僅僅強調研究人體的遺留物, 並且對他們所 存在的一切作整體的分析及解釋, 這包括考古學上, 社會文化上及政治情景上以及人類生活環境上的擺置。 因為対生物考古學的研究, 有愈來愈多的人有興趣。因此有必要發行一份新的期刊來刊登經過專家審核合格 的文章, 能這樣的話, 對這個學科在全球性的融合及發展會有幫助。在介紹生物考古學這一期, 我們追朔到這 個領域的源頭以及不同生物考古學派的發展, 現在這些學派, 已融合成爲一個成熟的學科。然後我們把辦這 個刊物的宗旨及目標描述出來並強調刊在這一期的每篇文章都符合我們刊物的目標。最後作為刊物的共同總 編輯, 我們對現代及未來生物考古學發展的方向也陳述了我們的視野。為這個領域及這刊物的總體觀, 我們 希望能鼓舞討論及促進國際間投稿。我們有意使國際生物考古學這刊物能加強這個領域的發展以及促進學 者及大衆對我們共同研究產生興趣。

\section{References Cited}

Agarwal, Sabrina C. 2012. The past of sex, gender, and health: Bioarchaeology of the aging skeleton. American Anthropologist 114(2):322-335. DOI: 10.1111/j.1548-1433.2012.01428.x.

Agarwal, Sabrina C. 2016. Bone morphologies and histories: Life course approaches in bioarchaeology. American Journal of Physical Anthropology Supplement: Yearbook of Physical Anthropology 159(S61):130-149. DOI: 10.1002/ajpa.22905.

Agarwal, Sabrina C., and Bonnie A. Glencross. 2011. Building a social bioarchaeology. In Social Bioarchaeology, edited by Sabrina C. Agarwal and Bonnie A. Glencross. Blackwell, Malden, MA, pp. 1-11.

Amoroso, Alexandra, Susana J. Garcia, and Hugo F. V. Cardoso. 2014. Age at death and linear enamel hypoplasias: Testing the effects of childhood stress and adult socioeconomic circumstances in premature mortality. American Journal of Human Biology 26(4):461-468. DOI: 10.1002/ajhb.22547.

Anastasiou, Evilena, and Piers D. Mitchell. 2013. Palaeopathology and genes: Investigating the genetics of infectious diseases in excavated human skeletal remains and mummies from past populations. Gene 528:33-40. DOI: 10.1016/j.gene.2013.06.017.

Appleby, Joanna E. P. 2010. Why we need an archaeology of old age, and a suggested approach. Norwegian Archaeological Review 43(2):145-168. DOI: 10.1080/00293652.2010.531582.

Armelagos, George J. 2003. Bioarchaeology as anthropology. Archaeological Papers of the American Anthropological Association 13:27-40. DOI: 10.1525/ap3a.2003.13.1.27.

Armelagos, George J., Alan H. Goodman, Kristin N. Harper, and Michael L. Blakey. 2009. Enamel hypoplasia and early mortality: Bioarcheological support for the Barker hypothesis. Evolutionary Anthropology 18(6): 261-271. DOI: 10.1002/evan.20239.

Armelagos, George J., and Dennis P. Van Gerven. 2003. A century of skeletal biology and paleopathology: Contrasts, contradictions, and conflicts. American Anthropologist 105(1):53-64. DOI: 10.1525/aa.2003.105.1.53

Atalay, Sonya. 2006. Indigenous archaeology as decolonizing practice. American Indian Quarterly 30(3):280-310. DOI: 10 .1353/aiq.2006.0015.

Baadsgaard, Aubrey, Alexis T. Boutin, and Jane E. Buikstra, eds. 2011. Breathing New Life into the Evidence of Death: Contemporary Approaches to Bioarchaeology. School for Advanced Research Press, Santa Fe.
Baker, Brenda J. 2016. Biocultural investigations of ancient Nubia. In New Directions in Biocultural Anthropology, edited by Molly K. Zuckerman and Debra L. Martin. Wiley, Hoboken, NJ, pp. 181-199.

Baker, Brenda J., and Katelyn L. Bolhofner. 2013. Biological and social implications of a medieval burial from Cyprus for understanding leprosy in the past. International Journal of Paleopathology 4(2014):17-24. DOI: 10.1016/j.ijpp.2013.08.006.

Baker, Brenda J., and Takeyuki Tsuda, eds. 2015. Migration and Disruptions: Toward a Unifying Theory of Ancient and Contemporary Migrations. University Press of Florida, Gainesville.

Beatrice, Jared S., and Angela Soler. 2016. Skeletal indicators of stress: A component of the biocultural profile of undocumented migrants in southern Arizona. Journal of Forensic Science 61(5):1164-1172. DOI: 10.1111/1556-4029.13131.

Beaumont, Julia, Andrew Gledhill, Julia Lee-Thorp, and Janet Montgomery. 2013. Childhood diet: A closer examination of the evidence from dental tissues using stable isotope analysis of incremental human dentine. Archaeometry 55(2):277-295. DOI: $10.1111 /$ j.1475-4754.2012.00682.x.

Beaumont, Julia, and Janet Montgomery. 2016. The Great Irish Famine: Identifying starvation in the tissues of victims using stable isotope analysis of bone and incremental dentine collagen. PLoS ONE 11(8):e0160065. DOI: 10.1371/journal.pone .0160065 .

Beaumont, Julia, Janet Montgomery, Jo Buckberry, and Mandy Jay. 2015. Infant mortality and isotopic complexity: New approaches to stress, maternal health, and weaning. American Journal of Physical Anthropology 157:441-457. DOI: 10.1002 /ajpa.22736.

Bentley, R. Alexander, Katharine Cox, Nancy Tayles, Charles Higham, Colin Macpherson, Geoff Nowell, Matthew Cooper, and Tina E. F. Hayes. 2009. Community diversity at Ban Lum Khao, Thailand: Isotopic evidence from the skeletons. Asian Perspectives 48:79-97. DOI: 10.1353/asi.0.0017.

Binder, Michaela, and Neal Spencer. 2014. The bioarchaeology of Amara West in Nubia: Investigating the impacts of political, cultural and environmental change on health and diet. In $R e$ garding the Dead: Human Remains in the British Museum, edited by Alexandra Fletcher, Daniel Antoine, and J. D. Hill. British Museum Press, London, pp. 123-136.

Binford, Lewis R. 1971. Mortuary practices: Their study and their potential. In Approaches to the Social Dimensions of Mortuary 
Practices, edited by James A. Brown. Memoirs of the Society for American Archaeology No. 25. Society for American Archaeology, Washington, DC, pp. 6-29.

Bocquet-Appel, Jean-Pierre, and Claude Masset. 1982. Farewell to paleodemography. Journal of Human Evolution 11:321-333.

Boldsen, Jesper L. 2006. Early childhood stress and adult age mortality-A study of dental enamel hypoplasia in the medieval Danish village of Tirup. American Journal of Physical Anthropology 132(2007):59-66. DOI: 10.1002/ajpa.20467.

Boldsen, Jesper L., George R. Milner, Lyle W. Konigsberg, and James W. Wood. 2002. Transition analysis: A new method for estimating age from skeletons. In Paleodemography: Age Distributions from Skeletal Samples, edited by Robert D. Hoppa and James W. Vaupel. Cambridge University Press, New York, pp. 73-106.

Booth, Thomas J., Rebecca C. Redfern, and Rebecca Gowland. 2016. Immaculate conceptions: Micro-CT analysis of diagenesis in Romano-British infant skeletons. Journal of Archaeological Science 74:124-134. DOI: 10.1016/j.jas.2016.08.007.

Bos, Kirsten I., Kelly M. Harkins, Alexander Herbig, Mireia Coscolla, Nico Weber, Iñaki Comas, Stephen A. Forrest, Josephine M. Bryant, Simon R. Harris, Verena J. Schuenemann, Tessa J. Campbell, Kerttu Majander, Alicia K.Wilbur, Ricardo A. Guichon, Dawnie L. Wolfe Steadman, Della Collins Cook, Stefan Niemann, Marcel A. Behr, Martin Zumarraga, Ricardo Bastida, Daniel Huson, Kay Nieselt, Douglas Young, Julian Parkhill, Jane E. Buikstra, Sebastien Gagneux, Anne C. Stone, and Johannes Krause. 2014. Pre-Columbian mycobacterial genomes reveal seals as a source of New World human tuberculosis. $\mathrm{Na}$ ture 514:494-497. DOI: 10.1038/naturel3591.

Bos, Kirsten I., Verena J. Schuenemann, G. Brian Golding, Hernán A. Burbano, Nicholas Waglechner, Brian K. Coombes, Joseph B. McPhee, Sharon N. DeWitte, Matthias Meyer, Sarah Schmedes, James Wood, David J. D. Earn, D. Ann Herring, Peter Bauer, Hendrik N. Poinar, and Johannes Krause. 2011. A draft genome of Yersinia pestis from victims of the Black Death. Nature 478:506-510. DOI: 10.1038/nature10549.

Bourbou, Chryssi, Benjamin T. Fuller, Sandra J. Garvie-Lok, and Michael P. Richards. 2013. Nursing mothers and feeding bottles: Reconstructing breastfeeding and weaning patterns in Greek Byzantine populations (6th-15th centuries AD) using carbon and nitrogen stable isotope ratios. Journal of Archaeological Science 40:3903-3913. DOI: 10.1016/j.jas.2013.04.020.

Brickley, Megan, and Jacqueline I. McKinley, eds. 2004. Guidelines to the Standards for Recording Human Remains. IFA Paper No. 7. British Association for Biological Anthropology and Osteoarchaeolgy and Institute of Field Archaeologists, Southampton and Reading.

Brooks, Sheilagh T., and Judith M. Suchey. 1990. Skeletal age determination based on the os pubis: A comparison of the Acsádi-Nemeskéri and Suchey-Brooks methods. Human Evolution 5(3):227-238.

Brothwell, Don R. 1967. The bio-cultural background to disease. In Diseases in Antiquity, edited by Don R. Brothwell and Andrew T. Sandison. Charles C. Thomas, Springfield, IL, pp. 56-68.

Buckley, Richard, Mathew Morris, Jo Appleby, Turi King, Deirdre O'Sullivan, and Lin Foxhall. 2013. 'The king in the car park': New light on the death and burial of Richard III in the Grey Friars church, Leicester, in 1485. Antiquity 87:519-538. DOI: 10.1017/S0003598X00049103.

Buckley, Stephen, Donatella Usai, Tina Jakob, Anita Radini, and Karen Hardy. 2014. Dental calculus reveals unique insights into food items, cooking and plant processing in prehistoric central Sudan. PLoS ONE 9(7):e100808, 1-10. DOI: 10.1371 /journal.pone.0100808.
Buikstra, Jane E. 1977. Biocultural dimensions of archaeological study: A regional perspective. In Biocultural Adaptation in Prehistoric America, edited by Robert L. Blakely. Proceedings of the Southern Anthropological Society No. 11. University of Georgia Press, Athens, pp. 67-84.

Buikstra, Jane E., Aubrey Baadsgaard, and Alexis T. Boutin. 2011. Introduction. In Breathing New Life into the Evidence of Death: Contemporary Approaches to Bioarchaeology, edited by Aubrey Baadsgaard, Alexis T. Boutin, and Jane E. Buikstra. School for Advanced Research Press, Santa Fe, pp. 3-26.

Buikstra, Jane E., and Lane A. Beck, eds. 2006. Bioarchaeology: The Contextual Analysis of Human Remains. Academic Press, Boston.

Buikstra, Jane E., and Lyle W. Konigsberg. 1985. Paleodemography: Critiques and controversies. American Anthropologist 87:316-333.

Buikstra, Jane E., and Douglas H. Ubelaker, eds. 1994. Standards for Data Collection from Human Skeletal Remains. Arkansas Archeological Survey Research Series 44, Fayetteville.

Burt, Nicole M., and Sandra Garvie-Lok. 2013. A new method of dentine microsampling of deciduous teeth for stable isotope ratio analysis. Journal of Archaeological Science 40(11):38543864. DOI: 10.1016/j.jas.2013.05.022.

Buzon, Michele R., and Antonio Simonetti. 2013. Strontium isotope $\left({ }^{87} \mathrm{Sr} /{ }^{86} \mathrm{Sr}\right)$ variability in the Nile Valley: Identifying residential mobility during ancient Egyptian and Nubian sociopolitical changes in the New Kingdom and Napatan Periods. American Journal of Physical Anthropology 151(1):1-9. DOI: 10.1002/ajpa .22235 .

Buzon, Michele R., Stuart Tyson Smith, and Antonio Simonetti. 2016. Entanglement and the formation of the ancient Nubian Napatan state. American Anthropologist 118(2):284-300. DOI: 10.1111/aman.12524.

Cabana, Graciela S., and Jeffery J. Clark, eds. 2011. Rethinking Anthropological Perspectives on Migration. University Press of Florida, Gainesville.

Carr, Christopher, and D. Troy Case, eds. 2005. Gathering Hopewell: Society, Ritual, and Ritual Interaction. Kluwer Academic/Plenum Publishers, New York.

Case, D. Troy, and Christopher Carr. 2008. The Scioto Hopewell and their Neighbors. Springer, New York.

Chamberlain, Andrew. 2000. Problems and prospects in palaeodemography. In Human Osteology in Archaeology and Forensic Science, edited by Margaret Cox and Simon Mays. Greenwich Medical Media, London, pp. 101-115.

Chapman, Robert, Ian Kinnes, and Klavs Randsborg. 1981. The Archaeology of Death: New Directions in Archaeology. Cambridge University Press, New York.

Clark, John Grahame Douglas. 1972. Star Carr: A Case Study in Bioarchaeology. Addison-Wesley Module in Anthropology 10. Addison-Wesley, Reading, MA.

Crandall, John J., and Haagen D. Klaus. 2014. Advancements, challenges, and prospects in the paleopathology of scurvy: Current perspectives on vitamin C deficiency in human skeletal remains. International Journal of Paleopathology 5:1-8. DOI: 10.1016/j.ijpp.2014.04.005.

Crespo, Fabian A., Christopher K. Klaes, Andrew E. Switala, and Sharon N. DeWitte. 2016. Do leprosy and tuberculosis generate a systemic inflammatory shift? Setting the ground for a new dialogue between experimental immunology and bioarchaeology. American Journal of Physical Anthropology 162:143156. DOI 10.1002/ajpa.23104.

Crossland, Zoë, and Rosemary A. Joyce, eds. 2015. Disturbing Bodies: Perspectives on Forensic Anthropology. School for Advanced Research Press, Santa Fe. 
Crowder, Christian, and Sam Stout, eds. 2011. Bone Histology: An Anthropological Perspective. CRC Press, Boca Raton.

de la Cova, Carlina. 2010. Cultural patterns of trauma among 19thcentury-born males in cadaver collections. American Anthropologist 112(4): 589-606. DOI: 10.1111/j.1548-1433.2010.01278.x.

de Melo, Fernando Lucas, Joana Carvalho Moreira de Mello, Ana Maria Fraga, Kelly Nunes, and Sabine Eggers. 2010. Syphilis at the crossroad of phylogenetics and paleopathology. PLoS Neglected Tropical Diseases 4(1):e575, 1-11. DOI: 10.1371/journal .pntd.0000575.

DeWitte, Sharon N. 2009. The effect of sex on risk of mortality during the Black Death in London, A.D. 1349-1350. American Journal of Physical Anthropology 139:222-234. DOI: 10.1002 /ajpa.20974.

DeWitte, Sharon N. 2010. Sex differentials in frailty in medieval England. American Journal of Physical Anthropology 143(2): 285-297. DOI: 10.1002/ajpa.21316.

DeWitte, Sharon N. 2014a. Differential survival among individuals with active and healed periosteal new bone formation. International Journal of Paleopathology 7:38-44. DOI: 10.1016 /j.ijpp.2014.06.001.

DeWitte, Sharon N. 2014b. Health in post-Black Death London (1350-1538): Age patterns of periosteal new bone formation in a post-epidemic population. American Journal of Physical Anthropology 155:260-267. DOI: 10.1002/ajpa.22510.

DeWitte, Sharon N., and Jelena Bekvalac. 2010. Oral health and frailty in the medieval English cemetery of St. Mary Graces. American Journal of Physical Anthropology 142(3):341-354. DOI: 10.1002/ajpa.21228.

DeWitte, Sharon N., and Gail Hughes-Morey. 2012. Stature and frailty during the Black Death: The effect of stature on risks of epidemic mortality in London, A.D. 1348-1350. Journal of Archaeological Science 39:1412-1419. DOI: 10.1016/j.jas.2012.01.019.

DeWitte, Sharon N., and Christopher M. Stojanowski. 2015. The osteological paradox 20 years later: Past perspectives, future directions. Journal of Archaeological Research 23(4):397-450. DOI: 10.1007/s10814-015-9084-1.

DeWitte, Sharon N., and James W. Wood. 2008. Selectivity of Black Death mortality with respect to preexisting health. Proceedings of the National Academy of Sciences 105(5):1436-1441. DOI: 10.1073/pnas.0705460105.

D’Ortenzio, Lori D., Megan Brickley, Henry Schwarcz, and Tracy Prowse. 2015. You are not what you eat during physiological stress: Isotopic evaluation of human hair. American Journal of Physical Anthropology 157:374-388. DOI: 10.1002/ajpa.22722.

Duday, Henri. 1978. Archéologie funéraire et anthropologie: Application des relevés et de l'étude ostéologique à l'interprétation de quelques sépultures pré- et protohistoriques du midi de la France. Cahiers d'Anthropologie 1:55-101.

Duday, Henri. 2006. L'archéoethanatologie ou l'archéologie de la mort (Archaeothanatology or the archaeology of death. Translated by Christopher J. Knüsel. In Social Archaeology of Funerary Remains, edited by Rebecca Gowland and Christopher Knüsel. Oxbow Books, Oxford, pp. 30-56.

Duday, Henri. 2009. The Archaeology of the Dead: Lectures in Archaeothanatology. Studies in Funerary Archaeology, vol. 3. Translated by Anna Maria Cipriani and John Pearce. Oxbow Books, Oxford.

Dupras, Tosha L., and Matthew W. Tocheri. 2007. Reconstructing infant weaning histories at Roman period Kellis, Egypt using stable isotope analysis of dentition. American Journal of Physical Anthropology 134(1):63-74. DOI 10.1002/ajpa.20639.

Eerkens, Jelmer W., and Eric J. Bartelink. 2013. Sex-biased weaning and early childhood diet among Middle Holocene hunter-gatherers in central California. American Journal of Physical Anthropology 152(4):471-483. DOI: 10.1002/ajpa .22384 .

Eerkens, Jelmer W., Ada G. Berget, and Eric J. Bartelink. 2011. Estimating weaning and early childhood diet from serial micro-samples of dentin collagen. Journal of Archaeological Science 38(11):3101-3111. DOI: 10.1016/j.jas.2011.07.010.

Fraser, R. A., A. Bogaard, M. Schäfer, R. Arbogat, and T. H. E. Heaton. 2013. Integrating botanical, faunal and human stable carbon and nitrogen isotope values to reconstruct land use and palaeodiet at LBK Vaihingen an der Enz, Baden-Württemberg. World Archaeology 45(3):492-517. DOI: 10.1080/00438243.2013.820649.

Geller, Pamela L. 2005. Skeletal analysis and theoretical complications. World Archaeology 37(4):597-609. DOI: 10.1080/0043 8240500404391

Geller, Pamela L. 2009. Bodyscapes, biology, and heteronormativity. American Anthropologist 111(4):504-516. DOI: 10.1111/j 1548-1433.2009.01159.x.

Geller, Pamela L. 2017. The Bioarchaeology of Socio-Sexual Lives: Queering Common Sense About Sex, Gender, and Sexuality. Springer, Cham, Switzerland. DOI: 10.1007/978-3-319-40995-5.

Gokhman, David, Eitan Lavi, Kay Prüfer, Mario F. Fraga, José A. Riancho, Janet Kelso, Svante Pääbo, Eran Meshorer, and Liran Carmel. 2014. Reconstructing the DNA methylation maps of the Neandertal and the Denisovan. Science 344(6183):523-527. DOI: $10.1126 /$ science.1250368.

Goldstein, Lynne. 2006. Mortuary analysis and bioarchaeology. In Bioarchaeology: The Contextual Analysis of Human Remains, edited by Jane E. Buikstra and Lane A. Beck. Academic Press, Boston, pp. 375-387.

Gowland, Rebecca L. 2009. Age, ageism and osteological bias: The evidence from late Roman Britain. Journal of Roman Archaeology supplementary series 65:153-160.

Gowland, Rebecca L. 2015a. Elder abuse: Evaluating the potentials and problems of diagnosis in the archaeological record. International Journal of Osteoarchaeology 26(2016):514-523. DOI: 10.1002/oa.2442.

Gowland, Rebecca L. 2015b. Entangled lives: Implications of the Developmental Origins of Health and Disease hypothesis for bioarchaeology and the life course. American Journal of Physical Anthropology 158(4):530-540. DOI: 10.1002/ajpa.22820.

Gregoricka, Lesley A. 2014. Assessing life history from commingled assemblages: The biogeochemistry of inter-tooth variability in Bronze Age Arabia. Journal of Archaeological Science 47:10-21. DOI: 10.1016/j.jas.2014.04.004 0305-4403.

Gregoricka, Lesley A., and Susan G. Sheridan. 2012. Food for thought: Isotopic evidence for dietary and weaning practices in a Byzantine urban monastery in Jerusalem. In Bioarchaeology and Behavior: The People of the Ancient Near East, edited by Megan A. Perry. University Press of Florida, Gainesville, pp. 80-114.

Gregoricka, Lesley A., and Susan G. Sheridan. 2017. Continuity or conquest? A multi-isotope approach to investigating identity in the Early Iron Age of the southern Levant. American Journal of Physical Anthropology 162(1):73-89. DOI: 10.1002/ajpa.23086.

Gregoricka, Lesley A., Susan G. Sheridan, and M. Schirtzinger. 2017. Reconstructing life histories using multi-tissue stable isotope analysis of commingled remains from St. Stephen's Monastery in Jerusalem: Limitations and potential. Archaeometry 59(1):148-163. DOI: 10.1111/arcm.12227.

The Greyfriars Research Team with Maev Kennedy and Lin Foxhall. 2015. The Bones of a King: Richard III Rediscovered. Wiley, Chichester.

Halcrow, Siân E., and Nancy Tayles. 2011. The bioarchaeological investigation of children and childhood. In Social Bioarchaeology, edited by Sabrina C. Agarwal and Bonnie A. Glencross. Blackwell, Malden, MA, pp. 333-360. 
Harkins, Kelly M., and Anne C. Stone. 2014. Ancient pathogen genomics: Insights into timing and adaptation. Journal of Human Evolution 29(2015):137-149. DOI: 10.1016/j.jhevol.2014.11.002.

Harrod, Ryan P., and Debra L. Martin. 2014. Bioarchaeology of Climate Change and Violence: Ethical Considerations. Springer, New York.

Hassett, Brenna R. 2014. Missing defects? A comparison of microscopic and macroscopic approaches to identifying linear enamel hypoplasia. American Journal of Physical Anthropology 153(3):463-472. DOI:10.1002/ajpa.22445.

Henderson, Charlotte Y., and Francisca Alves Cardoso. 2012. Special issue: Entheseal changes and occupation: Technical and theoretical advances and their applications. International Journal of Osteoarchaeology 23(2013):127-134. DOI: 10.1002/oa.2298.

Henderson, Rowena C., Julia Lee-Thorp, and Louise Loe. 2014. Early life histories of the London poor using $\delta^{13} \mathrm{C}$ and $\delta^{15} \mathrm{~N}$ stable isotope incremental dentine sampling. American Journal of Physical Anthropology 154(4):585-598. DOI: 10.1002/ajpa.22554.

Herrmann, Nicholas P. 2002. GIS applied to bioarchaeology: An example from the Río Talgua caves in northeast Honduras. Journal of Cave and Karst Studies 64(1):17-22.

Herrmann, Nicholas P., Joanne L. Devlin, and Jessica C. Stanton. 2014. Bioarchaeological spatial analysis of the Walker-Noe Crematory (15GD56). In Commingled and Disarticulated Human Remains: Working Toward Improved Theory, Method, and Data, edited by Anna J. Osterholtz, Kathryn M. Baustian, and Debra L. Martin. Springer, New York, pp. 51-66. DOI: 10.1007 1978-1-4614-7560-6_4.

Hollimon, Sandra E. 2011. Sex and gender in bioarchaeological research: Theory, method, and interpretation. In Social Bioarchaeology, edited by Sabrina C. Agarwal and Bonnie A. Glencross. Blackwell, Malden, MA, pp. 149-182.

Hoppa, Robert D., and James W. Vaupel, eds. 2002. Paleodemography: Age Distributions from Skeletal Samples. Cambridge University Press, New York.

Hubbard, Amelia, Debbie Guatelli-Steinberg, and Paul W. Sciulli. 2009. Under restrictive conditions, can the widths of linear enamel hypoplasias be used as relative indicators of stress episode duration? American Journal of Physical Anthropology 138(2):177-189. DOI: 10.1002/ajpa.20917.

Iacumin, Paola, Antonietta Di Matteo, Donatella Usai, Sandro Salvatori, and Giampiero Venturelli. 2016. Stable isotope study on ancient populations of central Sudan: Insights on their diet and environment. American Journal of Physical Anthropology 160:498-518. DOI: 10.1002/ajpa.22987.

İşcan, M. Yaşar, Susan R. Loth, and Ronald K. Wright. 1984a. Age estimation from the rib by phase analysis: White females. Journal of Forensic Sciences 30(3):853-863.

İşcan, M. Yaşar, Susan R. Loth, and Ronald K. Wright. 1984b. Age estimation from the rib by phase analysis: White males. Journal of Forensic Sciences 29(4):1094-1104.

Jackes, Mary. 2011. Representativeness and bias in archaeological skeletal samples. In Social Bioarchaeology, edited by Sabrina C. Agarwal and Bonnie A. Glencross. Blackwell, Malden, MA, pp. 107-146.

Jurmain, Robert, Francisca Alves Cardoso, Charlotte Henderson, and Sébastien Villotte. 2012. Bioarchaeology's Holy Grail: The reconstruction of activity. In A Companion to Paleopathology, edited by Anne L. Grauer. Blackwell, Malden, MA, pp. 531-552.

Kakaliouras, Ann M. 2012. An anthropology of repatriation: Contemporary physical anthropological and Native American ontologies of practice. Current Anthropology 53(S5):S210S221. DOI: $10.1086 / 662331$.

Kakaliouras, Ann M. 2017. NAGPRA and repatriation in the 21st century: Shifting the discourse from benefits to responsibilities. Bioarchaeology International 1(3), in press.
Katzenberg, M. Anne. 2012. The ecological approach: Understanding past diet and the relationship between diet and disease. In A Companion to Paleopathology, edited by Anne L. Grauer. Blackwell, Malden, MA, pp. 97-113.

Kaupová, Sylva, Estelle Herrscher, Peter Velemínský, Sandrine Cabut, Lumír Poláček, and Jaroslav Brůžek. 2014. Urban and rural infant-feeding practices and health in early medieval central Europe (9th-10th century, Czech Republic). American Journal of Physical Anthropology 155(4):635-651. DOI: 10.1002 /ajpa.22620.

Kendall, Ellen J., Janet Montgomery, Jane A. Evans, Christina Stantis, and V. Mueller. 2013. Mobility, mortality, and the Middle Ages: Identification of migrant individuals in a 14th century Black Death cemetery population. American Journal of Physical Anthropology 150:210-222. DOI: 10.1002/ajpa.22194.

Killgrove, Kristina, and Janet Montgomery. 2016. All roads lead to Rome: Exploring human migration to the Eternal City through biochemistry of skeletons from two Imperial-Era cemeteries (1st-3rd c AD). PLoS ONE 11(2):e0147585. DOI: 10 .1371/journal.pone.0147585.

Klaus, Haagen D. 2014. Frontiers in the bioarchaeology of stress and disease: Cross-disciplinary perspectives from pathophysiology, human biology, and epidemiology. American Journal of Physical Anthropology 155:294-308. DOI: 10.1002/ajpa.22574.

Knudson, Kelly J. 2011. Identifying archaeological human migration using biogeochemistry: Case studies from the SouthCentral Andes. In Rethinking Anthropological Perspectives on Migration, edited by Graciela S. Cabana and Jeffery J. Clark. University Press of Florida, Gainesville, pp. 231-247.

Knudson, Kelly J., Paul S. Goldstein, Allisen Dahlstedt, Andrew Somerville, and Margaret J. Schoeninger. 2014. Paleomobility in the Tiwanaku Diaspora: Biogeochemical Analyses at Rio Muerto, Moquegua, Peru. American Journal of Physical Anthropology 155:405-421. DOI: 10.1002/ajpa.22584

Knudson, Kelly J., and Christopher M. Stojanowski. 2008. New directions in bioarchaeology: Recent contributions to the study of human social identities. Journal of Archaeological Research 16(4):397-432. DOI: 10.1007/s10814-008-9024-4.

Knudson, Kelly J., and Christopher M. Stojanowski, eds. 2009. Bioarchaeology and Identity in the Americas. University Press of Florida, Gainesville.

Knüsel, Christopher J. 2010. Bioarchaeology: A synthetic approach. Bulletins et Mémoires de la Société d'Anthropologie de Paris 22:62-73. DOI: 10.1007/s13219-010-0003-1.

Knüsel, Christopher J., and Martin J. Smith. 2014. The Routledge Handbook of the Bioarchaeology of Human Conflict. Routledge, London.

Kuba, Cassandra L. 2012. Deadly borders: The role of forensic anthropology in Homeland Security in the southwestern United States. Homeland Security Review 6(2):137-156.

Kurin, Danielle Shawn. 2016. The Bioarchaeology of Societal Collapse and Regeneration in Ancient Peru. Springer, Cham, Switzerland. DOI: 10.1007/978-3-319-28404-0.

Larsen, Clark Spencer. 1997. Bioarchaeology: Interpreting Behavior from the Human Skeleton. Cambridge University Press, Cambridge.

Larsen, Clark Spencer. 2015. Bioarchaeology: Interpreting Behavior from the Human Skeleton. 2nd ed. Cambridge University Press, Cambridge.

Larsen, Clark Spencer, and Phillip L. Walker. 2010. Bioarchaeology: Health, lifestyle, and society in recent human evolution. In A Companion to Biological Anthropology, edited by Clark Spencer Larsen. Blackwell, Malden, MA, pp. 379-394.

Lindo, John, Emilia Huerta-Sánchez, Shigeki Nakagome, Morten Rasmussen, Barbara Petzelt, Joycelynn Mitchell, Jerome S. Cybulski, Eske Willerslev, Michael DeGiorgio, and Ripan S. 
Malhi. 2016. A time transect of exomes from a Native American population before and after European contact. Nature Communications 7:13175, 1-11. DOI: 10.1038/ncomms13175.

Littleton, Judith. 2011. Moving from the canary in the coalmine: Modeling childhood in Bahrain. In Social Bioarchaeology, edited by Sabrina C. Agarwal and Bonnie A. Glencross. Blackwell, Malden, MA, pp. 361-389.

Lovejoy, C. Owen, Richard S. Meindl, Thomas R. Pryzbeck, and Robert P. Mensforth. 1985. Chronological metamorphosis of the auricular surface of the ilium: A new method for the determination of adult skeletal age at death. American Journal of Physical Anthropology 68:15-28. DOI: 10.1002/ajpa.1330680103.

Marklein, Kathryn E., Rachael E. Leahy, and Douglas E. Crews. 2016. In sickness and in death: Assessing frailty in human skeletal remains. American Journal of Physical Anthropology 161:208-225. DOI: 10.1002/ajpa.23019.

Márquez-Grant, Nicholas, and Linda Fibiger, eds. 2011. The Routledge Handbook of Archaeological Human Remains and Legislation: An International Guide to Laws and Practice in the Excavation and Treatment of Archaeological Human Remains. Routledge, New York.

Marsteller, Sara J., Christina Torres-Rouff, and Kelly J. Knudson. 2011. Pre-Columbian Andean sickness ideology and the social experience of leishmaniasis: A contextualized analysis of bioarchaeological and paleopathological data from San Pedro de Atacama, Chile. International Journal of Paleopathology 1:2434. DOI: 10.1016/j.ijpp.2011.02.001.

Martin, Debra L., Ryan P. Harrod, and Ventura R. Pérez. 2012. The Bioarchaeology of Violence. University Press of Florida, Gainesville.

Martin, Debra L., Ryan P. Harrod, and Ventura R. Pérez. 2013. Bioarchaeology: An Integrated Approach to Working with Human Remains. Springer, New York.

Martin, Debra L., and Caryn Tegtmeyer. 2017. Bioarchaeology of Women and Children in Times of War: Case Studies from the Americas. Springer, Cham, Switzerland. DOI: 10.1007/978-3 -319-48396-2.

Martin, Debra L., and Molly K. Zuckerman. 2016. A biocultural tribute to a biocultural scholar: Professor George J. Armelagos, May 22, 1936-May 15, 2014. In New Directions in Biocultural Anthropology, edited by Molly K. Zuckerman and Debra L. Martin. Wiley, Hoboken, NJ, pp. 1-6.

McIlvaine, Britney Kyle. 2013. Implications of reappraising the iron-deficiency anemia hypothesis. International Journal of Osteoarchaeology 25(2015):997-1000. DOI: 10.1002/oa.2383.

Milner, George R., James W. Wood, and Jesper L. Boldsen. 2008. Advances in paleodemography. In Biological Anthropology of the Human Skeleton, 2nd ed., edited by M. Anne Katzenberg and Shelley R. Saunders. Wiley, Hoboken, NJ, pp. 561-600.

Müller, Romy, Charlotte A. Roberts, and Terence A. Brown. 2014. Genotyping of ancient Mycobacterium tuberculosis strains reveals historic genetic diversity. Proceedings of the Royal Society B 281:1-8. DOI: 10.1098/rspb.2013.3236.

Murphy, Melissa S., and Haagen D. Klaus, eds. 2017. Colonized Bodies, Worlds Transformed: Toward a Global Bioarchaeology of Contact and Colonialism. University Press of Florida, Gainesville.

Neil, Samantha, Jane Evans, Janet Montgomery, and Chris Scarre. 2016. Isotopic evidence for residential mobility of farming communities during the transition to agriculture in Britain. Royal Society Open Science 3:150522, 1-14. DOI: 10.1098/rsos.150522.

Nystrom, Kenneth C. 2014. The bioarchaeology of structural violence and dissection in the 19th-century United States. American Anthropologist 116(4):765-779. DOI: 10.1111/aman.12151.

Nystrom, Kenneth C. 2017. The Bioarchaeology of Dissection and Autopsy in the United States. Springer, Cham, Switzerland. DOI: $10.1007 / 978-3-319-26836-1$.
O’Donnabhain, Barra, and María Cecilia Lozada, eds. 2014. Archaeological Human Remains: Global Perspectives. Springer, Cham, Switzerland. DOI: 10.1007/978-3-319-06370-6.

Olsen, Karyn C., Christine D. White, Fred J. Longstaffe, Kristin von Heyking, George McGlynn, Gisela Grupe, and Frank J. Rühli. 2014. Intraskeletal isotopic compositions $\left(\delta^{13} \mathrm{C}, \delta^{15} \mathrm{~N}\right)$ of bone collagen: Nonpathological and pathological variation. American Journal of Physical Anthropology 153(4):598-604. DOI: 10.1002/ajpa.22459.

Pader, Ellen-Jane. 1982. Symbolism, Social Relations and the Interpretation of Mortuary Remains. BAR International Series, 130. British Archaeological Reports, Oxford.

Parker Pearson, Mike. 1982. Mortuary practices, society and ideology: An ethnoarchaeological study. In Symbolic and Structural Archaeology, edited by Ian Hodder. Cambridge University Press, Cambridge, pp. 99-113.

Parker Pearson, Mike. 1999. The Archaeology of Death and Burial. Texas A\&M University Press, College Station.

Parker Pearson, Mike, Andrew Chamberlain, Mandy Jay, Mike Richards, Alison Sheridan, Neil Curtis, Jane Evans, Alex Gibson, Margaret Hutchison, Patrick Mahoney, Peter Marshall, Janet Montgomery, Stuart Needham, Sandra O'Mahoney, Maura Pellegrini, and Neil Wilkin. 2016. Beaker people in Britain: Migration, mobility and diet. Antiquity 90(351):620637. DOI:10.15184/aqy.2016.72.

Paul, Kathleen S., Christopher M. Stojanowski, and Michelle M. Butler. 2013. Biological and spatial structure of an Early Classic Period cemetery at Charco Redondo, Oaxaca. American Journal of Physical Anthropology 152:217-229. DOI: 10.1002 /ajpa.22347.

Pérez, Ventura R. 2010. From the singing tree to the hanging tree: Structural violence and death within the Yaqui landscape. Landscapes of Violence 1(1):Article 9. Available at http://scholarworks.umass.edu/lov/vol1/iss1/9. Accessed March 22, 2017.

Perry, Megan A. 2014. Tracking the second epidemiological transition using bioarchaeological data on infant morbidity and mortality. In Modern Environments and Human Health: Revisiting the Second Epidemiological Transition, edited by Molly K. Zuckerman. Wiley Blackwell, Hoboken, NJ, pp. 225-241.

Pilloud, Marin A., and Clark Spencer Larsen. 2011. "Official" and "Practical" kin: Inferring social and community structure from dental phenotype at Neolithic Çatalhöyük, Turkey. American Journal of Physical Anthropology 145:519-530. DOI: 10.1002/ajpa.21520.

Piperata, Barbara A., Mark Hubbe, and Kammi K. Schmeer. 2014. Intra-population variation in anemia status and its relationship to economic status and self-perceived health in the Mexican Family Life Survey: Implications for bioarchaeology. American Journal of Physical Anthropology 155:210-220. DOI: 10.1002/ajpa.22543.

Prowse, Tracy. 2011. Diet and dental health through the life course in Roman Italy. In Social Bioarchaeology, edited by Sabrina C. Agarwal and Bonnie A. Glencross. Blackwell, Malden, MA, pp. 410-437.

Quinn, Colin P., and Jess Beck. 2016. Essential tensions: A framework for exploring inequality through mortuary archaeology and bioarchaeology. Open Archaeology 2:18-41. DOI: 10.1515 lopar-2016-0002.

Radini, Anita, Efthymia Nikita, Stephen Buckley, Les Copeland, and Karen Hardy. 2017. Beyond food: The multiple pathways for inclusion of materials into ancient dental calculus. American Journal of Physical Anthropology Supplement: Yearbook of Physical Anthropology 162(S63):71-83. DOI: 10.1002/ajpa.23147.

Rakita, Gordon F. M. 2014. Bioarchaeology as a process: An examination of bioarchaeological tribes in the USA. In Archaeological Human Remains: Global Perspectives, edited by Barra 
O’Donnabhain, and María Cecilia Lozada. Springer, Cham, Switzerland, pp. 213-234. DOI: 10.1007/978-3-319-06370-6_16. Redfern, Rebecca C. 2017. Injury and Trauma in Bioarchaeology: Interpreting Violence in Past Lives. Cambridge University Press, Cambridge.

Reinhard, Karl J., and Adauto Araújo. 2012. Synthesizing parasitology with archaeology in paleopathology. In The Global History of Paleopathology: Pioneers and Prospects, edited by Jane E. Buikstra and Charlotte A. Roberts. Oxford University Press, New York, pp. 751-764.

Reitsema, Laurie J., and Britney Kyle McIlvaine. 2014. Reconciling "stress" and "health" in physical anthropology: What can bioarchaeologists learn from the other sub-disciplines? American Journal of Physical Anthropology 155:181-185. DOI: 10.1002 /ajpa.22596.

Reitsema, Laurie J., and Giuseppe Vercellotti. 2012. Stable isotope evidence for sex- and status-based variations in diet and life history at medieval Trino Vercellese, Italy. American Journal of Physical Anthropology 148:589-600. DOI: 10.1002/ajpa.22085.

Reitsema, Laurie J., Giuseppe Vercellotti, and Rosa Boano. 2016. Subadult dietary variation at Trino Vercellese, Italy, and its relationship to adult diet and mortality. American Journal of Physical Anthropology 160:653-664. DOI: 10.1002/ajpa.22995.

Richards, Michael P., Simon Mays, and Benjamin T. Fuller. 2002. Stable carbon and nitrogen isotope values of bone and teeth reflect weaning age at the medieval Wharram Percy Site, Yorkshire, UK. American Journal of Physical Anthropology 119(3): 205-210. DOI: 10.1002/ajpa.10124.

Robb, John, Ernestine S. Elster, Eugenia Isetti, Christopher J. Knüsel, Mary Anne Tafuri, and Antonella Traverso. 2015. Cleaning the dead: Neolithic ritual processing of human bone at Scaloria Cave, Italy. Antiquity 89:39-54. DOI: 10.15184/aqy.2014.35.

Robbins Schug, Gwen. 2011. Bioarchaeology and Climate Change: A View from South Asian Prehistory. University Press of Florida, Gainesville.

Robbins Schug, Gwen, and Haviva M. Goldman. 2014. Birth is but our death begun: A bioarchaeological assessment of skeletal emaciation in immature human skeletons in the context of environmental, social, and subsistence transition. American Journal of Physical Anthropology 155(2):243-259. DOI: 10.1002 /ajpa.22536.

Roberts, Charlotte A. 2006. A view from afar: Bioarchaeology in Britain. In Bioarchaeology: The Contextual Analysis of Human Remains, edited by Jane E. Buikstra and Lane A. Beck. Academic Press, Boston, pp. 417-439.

Roberts, Charlotte A. 2009. Human Remains in Archaeology: A Handbook. Council for British Archaeology, York.

Roberts, Charlotte A., A. R. Millard, G. M. Nowell, D. R. Gröcke, C. G. Macpherson, D. G. Pearson, and D. H. Evans. 2013. Isotopic tracing of the impact of mobility on infectious disease: The origin of people with treponematosis buried in Hull, England, in the late medieval period. American Journal of Physical Anthropology 150:273-285. DOI: 10.1002/ajpa.22203.

Rühli, Frank J., and Salima Ikram. 2013. Purported medical diagnoses of Pharaoh Tutankhamun, c. 1325 BC. HOMO-Journal of Comparative Human Biology 65(2014):51-63. DOI: 10 .1016/j.jchb.2013.08.006.

Sallares, Robert, and Susan Gomzi. 2001. Biomolecular archaeology of malaria. Ancient Biomolecules 3:195-213.

Sandberg, Paul A., Matt Sponheimer, Julia Lee-Thorp, and Dennis Van Gerven. 2014. Intra-tooth stable isotope analysis of dentine: A step toward addressing selective mortality in the reconstruction of life history in the archaeological record. American Journal of Physical Anthropology 155(2):281-293. DOI: 10.1002/ajpa.22600.
Saul, Frank P. 1972. The Human Skeletal Remains of Altar de Sacrificios: An Osteobiographic Approach. Papers of the Peabody Museum of Archaeology and Ethnology, Harvard University, v. 63 , no. 2, Cambridge, MA.

Saul, Frank P., and Julie M. Saul. 1989. Osteobiography: A Maya example. In Reconstruction of Life from the Skeleton, edited by Mehmet Yaşar İşcan and Kenneth A. R. Kennedy. Alan R. Liss, New York, pp. 287-302.

Saunders, Shelley R., and Robert D. Hoppa. 1993. Growth deficit in survivors and non-survivors: Biological mortality bias in subadult skeletal samples. Yearbook of Physical Anthropology 36:127-151.

Saxe, Arthur A. 1970. Social Dimensions of Mortuary Practices. Ph.D. dissertation, University of Michigan, Ann Arbor.

Schnorr, Stephanie L., Krithivasan Sankaranarayanan, Cecil M. Lewis Jr., and Christina Warinner. 2016. Insights into human evolution from ancient and contemporary microbiome studies. Current Opinion in Genetics and Development 41:14-26. DOI: 10.1016/j.gde.2016.07.003.

Schuenemann, Verena J., Pushprendra Singh, Thomas A. Mendum, Ben Krause-Kyora, Günter Jäger, Kirsten I. Bos, Alexander Herbig, Christos Economou, Andrej Benjak, Philippe Busso, Almut Nebel, Jesper L. Boldsen, Anna Kjellström, Huihai Wu, Graham R. Stewart, G. Michael Taylor, Peter Bauer, Oona Y.-C. Lee, Houdini H. T. Wu, David E. Minnikin, Gurdyal S. Besra, Katie Tucker, Simon Roffey, Samba O. Sow, Stewart T. Cole, Kay Nieselt, and Johannes Krause. 2013. Genome-wide comparison of medieval and modern Mycobacterium leprae. Science 341(6142):179-183. DOI: 10.1126/science.1238286.

Sciulli, Paul W., and Robert A. Cook. 2016. Intracemetery biological variation at the Fort Ancient SunWatch Village. American Journal of Physical Anthropology 160:719-728. DOI: 10.1002 /ajpa.23001.

Shanks, Michael, and Christopher Y. Tilley. 1982. Ideology, symbolic power and ritual communication: A reinterpretation of Neolithic mortuary practices. In Symbolic and Structural Archaeology, edited by Ian Hodder. Cambridge University Press, Cambridge, pp. 129-154.

Shaw, Heidi, Janet Montgomery, Rebecca Redfern, Rebecca Gowland, and Jane Evans. 2015. Identifying migrants in Roman London using lead and strontium stable isotopes. Journal of Archaeological Science 66(2016):57-68. DOI: 10.1016/j.jas.2015 .12.001 0305-4403.

Sheridan, Susan Guise. 2017. Bioarchaeology in the ancient Near East: Challenges and future directions for the southern Levant. American Journal of Physical Anthropology Supplement: Yearbook of Physical Anthropology 162(S63):110-152. DOI: 10 .1002/ajpa.23149.

Smith, Rick W. A., Cara Monroe, and Deborah A. Bolnick. 2015. Detection of cytosine methylation in ancient DNA from five Native American populations using bisulfite sequencing. PLoS ONE 10(5):e0125344, 1-23. DOI: 10.1371/journal.pone.0125344.

Smith, Scott C., and Maribel Pérez Arias. 2015. From bodies to bones: Death and mobility in the Lake Titicaca basin, Bolivia. Antiquity 89:106-121. DOI: 10.15184.aqy.2014.32.

Smith-Guzmán, Nicole E. 2015. Cribra orbitalia in the ancient Nile Valley and its connection to malaria. International Journal of Paleopathology 10:1-12. DOI: 10.1016/j.ijpp.2015.03.001.

Smithsonian Institution. 2016. Osteoware: Standardized skeletal documentation software. https://osteoware.si.edu. Accessed May 1, 2017.

Sofaer, Joanna R. 2006a. Gender, bioarchaeology, and human ontogeny. In Social Archaeology of Funerary Remains, edited by Rebecca Gowland and Christopher Knüsel. Oxbow Books, Oxford, pp. 155-167. 
Sofaer, Joanna R. 2006b. The Body as Material Culture. Cambridge University Press, Cambridge.

Stodder, Ann L. W., and Ann Palkovich. 2012. The Bioarchaeology of Individuals. University Press of Florida, Gainesville.

Stojanowski, Christopher M. 2013. Mission Cemeteries, Mission Peoples: Historical and Evolutionary Dimensions of Intracemetery Bioarchaeology in Spanish Florida. University Press of Florida, Gainesville.

Stojanowski, Christopher M., and William N. Duncan. 2014. Engaging bodies in the public imagination: Bioarchaeology as social science, science, and humanities. American Journal of Human Biology 27:51-60. DOI: 10.1002/ajhb.22522.

Stojanowski, Christopher M., and William N. Duncan, eds. 2016. Studies in Forensic Biohistory: Anthropological Perspectives. Cambridge University Press, Cambridge.

Stone, Anne C., Alicia K. Wilbur, Jane E. Buikstra, and Charlotte A. Roberts. 2009. Tuberculosis and leprosy in perspective. American Journal of Physical Anthropology Supplement: Yearbook of Physical Anthropology 140(S49): 66-94. DOI 10.1002 /ajpa.21185.

Storey, Rebecca, Lourdes Márquez-Morfín, and Luis F. Núñez. 2012. Teotihuacan neighborhoods and the health of residents: The risks of preindustrial urban living. In The Neighborhood as a Social and Spatial Unit in Mesoamerican Cities, edited by M. Charlotte Arnauld, Linda R. Manzanilla, and Michael E. Smith. University of Arizona Press, Tuscon, pp. 117-131.

Sullivan, Amy. 2005. Prevalence and etiology of acquired anemia in medieval York, England. American Journal of Physical Anthropology 128:252-272. DOI: 10.1002/ajpa.20026.

Tarlow, Sarah, and Liv Nilsson Stutz, eds. 2013. The Oxford Handbook of Death and Burial. Oxford University Press, Oxford.

Temple, Daniel H. 2014. Plasticity and constraint in response to early-life stressors among Late/Final Jomon Period foragers from Japan: Evidence for life history trade-offs from incremental microstructures of enamel. American Journal of Physical Anthropology 155:537-545. DOI: 10.1002/ajpa.22606.

Temple, Daniel H., Vladimir I. Bazaliiskii, Olga I. Goriunova, and Andrzej W. Weber. 2013. Skeletal growth in early and late Neolithic foragers from the Cis-Baikal region of eastern Siberia. American Journal of Physical Anthropology 153(3):377-386. DOI: 10.1002/ajpa.22436.

Thompson, Jennifer L., Marta P. Alfonso-Durruty, and John J. Crandall, eds. 2014. Tracing Childhood: Bioarchaeological Investigations of Early Lives in Antiquity. University Press of Florida, Gainesville.

Tilley, Lorna. 2015. Theory and Practice in the Bioarchaeology of Care. Springer, Cham, Switzerland. DOI: 10.1007/978-3-319 -18860-7.

Tilley, Lorna, and Alecia A. Schrenk, eds. 2017. New Developments in the Bioarchaeology of Care: Further Case Studies and Expanded Theory. Springer, Cham, Switzerland. DOI: 10.1007 1978-3-319-39901-0.

Tsutaya, Takumi, and Minoru Yoneda. 2015. Reconstruction of breastfeeding and weaning practices using stable isotope and trace element analyses: A review. American Journal of Physical Anthropology Supplement: Yearbook of Physical Anthropology 156(S59):2-21. DOI: 10.1002/ajpa.22657.

Turner, Bethany L., and Valerie A. Andrushko. 2011. Partnerships, pitfalls, and ethical concerns in international bioarchaeology. In Social Bioarchaeology, edited by Sabrina C. Agarwal and Bonnie A. Glencross. Blackwell, Malden, MA, pp. 361-389.

Valentine, Benjamin. 2016. More than origins: Refining migration in the Indus civilization. In A Companion to South Asia in the Past, edited by Gwen Robbins Schug and Subhash R.
Walimbe. Wiley, Hoboken, NJ, pp. 187-204. DOI: 10.1002 19781119055280.ch12187.

Van Gerven, Dennis P., and George J. Armelagos. 1983. "Farewell to Paleodemography?" Rumors of its death have been greatly exaggerated. Journal of Human Evolution 12:353-360.

Vercellotti, Giuseppe, Barbara A. Piperata, Amanda M. Agnew, Warren M. Wilson, Darna L. Dufour, Julio C. Reina, Rosa Boano, Hedy M. Justus, Clark Spencer Larsen, Sam D. Stout, and Paul W. Sciulli. 2014. Exploring the multidimensionality of stature variation in the past through comparisons of archaeological and living populations. American Journal of Physical Anthropology 155(2):229-242. DOI: 10.1002/ajpa.22552.

Villotte, Sébastien, and Christopher J. Knüsel. 2012. Understanding entheseal changes: Definition and life course changes. International Journal of Osteoarchaeology 23(2013):135-146. DOI: 10.1002/oa.2289.

Warinner, Christina, and Cecil M. Lewis. 2015. Microbiome and health in past and present human populations. American Anthropologist 117(4):740-741. DOI: 10.1111/aman.12367.

Waters-Rist, Andrea L., Vladimir I. Bazaliiskii, Andrzej W. Weber, and M. Anne Katzenberg. 2011. Infant and child diet in Neolithic hunter-fisher-gatherers from Cis-Baikal, Siberia: Intra-long bone stable nitrogen and carbon isotope ratios. American Journal of Physical Anthropology 146:225-241. DOI: 10.1002/ajpa.21568.

Webb, Emily, Steven Thomson, Andrew Nelson, Christine White, Gideon Koren, Michael Rieder, and Stan Van Uum. 2009. Assessing individual systemic stress through cortisol analysis of archaeological hair. Journal of Archaeological Science 37(2010): 807-812. DOI: 10.1016/j.jas.2009.11.010.

Weisensee, Katherine E. 2013. Assessing the relationship between fluctuating asymmetry and cause of death in skeletal remains: A test of the Developmental Origins of Health and Disease hypothesis. American Journal of Human Biology 25(3):411-417. DOI: 10.1002/ajhb.22390.

Weiss-Krejci, Estella. 2011. The formation of mortuary deposits: Implications for understanding mortuary behavior of past populations. In Social Bioarchaeology, edited by Sabrina C. Agarwal and Bonnie A. Glencross. Blackwell, Malden, MA, pp. 68-106.

Weston, Darlene A. 2008. Investigating the specificity of periosteal reactions in pathology museum specimens. American Journal of Physical Anthropology 137:48-59. DOI: 10.1002/ajpa .20839.

Weston, Darlene A. 2009. Brief communication: Paleohistopathological analysis of pathology museum specimens: Can periosteal reaction microstructure explain lesion etiology? American Journal of Physical Anthropology 140:186-193. DOI: 10.1002/ajpa.21081.

Weston, Darlene A. 2012. Nonspecific infection in paleopathology: Interpreting periosteal reactions. In A Companion to $\mathrm{Pa}$ leopathology, edited by Anne L. Grauer. Blackwell, Malden, MA, pp. 492-512.

Wheeler, Sandra M. 2010. Nutritional and disease stress of juveniles from the Dakhleh Oasis, Egypt. International Journal of Osteoarchaeology 22(2012):219-234. DOI: 10.1002/oa.1201.

Wheeler, Sandra M., Lana Williams, Patrick Beauchesne, and Tosha L. Dupras. 2013. Shattered lives and broken childhoods: Evidence of physical child abuse in ancient Egypt. International Journal of Paleopathology 3:71-82. DOI: 10.1016/j.ijpp .2013.03.009.

White, Christine D., and Henry P. Schwarcz. 1994. Temporal trends in stable isotopes for Nubian mummy tissues. American Journal of Physical Anthropology 93(2):165-187. DOI: 10.1002 /ajpa.1330930203. 
Wilbur, Alicia K., and Anne C. Stone. 2012. Using ancient DNA techniques to study human disease. In The Global History of Paleopathology: Pioneers and Prospects, edited by Jane E. Buikstra and Charlotte A. Roberts. Oxford University Press, New York, pp. 703-717.

Wilhelmson, Helene, and Nicoló Dell'Unto. 2015. Virtual taphonomy: A new method integrating excavation and postprocessing in an archaeological context. American Journal of Physical Anthropology 157:305-321. DOI: 10.1002/ajpa.22715.

Wilson, Jeremy J. 2014. Paradox and promise: Research on the role of recent advances in paleodemography and paleoepidemiology to the study of "health" in Precolumbian societies. American Journal of Physical Anthropology 155:268-280. DOI: 10.1002/ajpa.22601.

Wood, James W., George R. Milner, Henry C. Harpending, and Kenneth M. Weiss. 1992. The osteological paradox: Problems of inferring prehistoric health from skeletal samples. Current Anthropology 33(4): 343-370.

Wright, Lori E. 2012. Immigration to Tikal, Guatemala: Evidence from stable strontium and oxygen isotopes. Journal of
Anthropological Archaeology 31:334-352. DOI: 10.1016/j.jaa.2012 .02 .001 .

Wright, Lori E., and Cassady J. Yoder. 2003. Recent progress in bioarchaeology: Approaches to the osteological paradox. Journal of Archaeological Research 11(1):43-70. DOI: 10.1023 /A:1021200925063.

Wrobel, Gabriel D., ed. 2014. The Bioarchaeology of Space and Place: Ideology, Power, and Meaning in Maya Mortuary Contexts. Springer, New York. DOI: 10.1007/978-1-4939-0479-2.

Zuckerman, Molly K., and George J. Armelagos. 2011. The origins of biocultural dimensions in bioarchaeology. In Social Bioarchaeology, edited by Sabrina C. Agarwal and Bonnie A. Glencross. Blackwell, Malden, MA, pp. 15-43.

Zuckerman, Molly K., and Debra L. Martin. 2016a. Introduction: The development of biocultural perspectives in anthropology. In New Directions in Biocultural Anthropology, edited by Molly K. Zuckerman and Debra L. Martin. Wiley, Hoboken, NJ, pp. 7-26.

Zuckerman, Molly K., and Debra L. Martin, eds. 2016b. New Directions in Biocultural Anthropology. Wiley, Hoboken, NJ. 